\title{
PENINGKATAN VISIBILITAS PENGAMBILAN KEPUTUSAN DIVISI AKUNTANSI DAN KEUANGAN DI PT SENTRA WIRA TAKTIKAL
}

\author{
Jeremmy Nathanael
}

\author{
Daya Adicipta Motora, Bandung \\ jeremmynathanael.limiadji@gmail.com
}

\begin{abstract}
ABSTRAK
Indonesia merupakan negara terpadat ke-4 di dunia menurut United States Census Bureau pada tahun 2018. Hal tersebut menyebabkan ada banyak variasi hobi yang dimiliki masing-masing individu, dan akan mengundang adanya bisnis-bisnis yang bervariasi pula dalam memenuhi permintaan atas hobi-hobi yang ada. Salah satunya adalah bisnis taktikal yang menjual peralatan taktikal kepada orang-orang dengan hobi airsoft-gun, menembak, dll., seperti PT Sentra Wira Taktikal.

Masalah yang dihadapi PT Sentra Wira Taktikal antara lain mengenai pencatatan transaksi yang tidak tervalidasi, tidak tercatat, dan tidak diolah dengan baik sehingga timbulnya kemungkinan terjadi kesalahan dalam penerimaan barang, kekeliruan dalam pengiriman barang, dll. Karena hal tersebut, data-data menjadi tidak dapat dipergunakan di kemudian hari yang mengakibatkan lemahnya keputusan-keputusan yang diambil. Karena itu, PT Sentra Wira Taktikal harus mengaplikasikan sistem informasi dalam membantu pemilik dalam melakukan pengambilan keputusan.

Untuk mencapai tujuan penelitian, penelitian ini menggunakan metode penelitian kualitatif dimana metode ini lebih menekankan pada aspek pemahaman secara mendalam terhadap suatu masalah. Teknik analisis yang digunakan adalah diagram Laudon yang akan ditunjang oleh alat-alat lainnya, seperti: Porter 5 Forces untuk analisis permasalahan eksternal, SWOT untuk analisis permasalahan internal, BCB untuk identifikasi kebutuhan, BPMN untuk menggambarkan proses bisnis, Tampilan Pengguna untuk membantu pengguna dalam mengakses sistem informasi, dan Decision tree dalam membentuk logika berpikir.

Berdasarkan hasil analisis tersebut, maka kontrol yang dihasilkan sesuai kebutuhan PT. Sentra Wira Taktikal adalah sistem yang mampu mendefinisikan proses bisnis secara terperinci dan meningkatkan visibilitas guna peningkatan visibilitas pengambilan keputusan.
\end{abstract}

Kata kunci: Sistem Informasi, Porter 5 Forces, SWOT, BCB, BPMN, User Interface, dan Decision Tree.

\section{ABSTRACT}

Indonesia is the 4th most populous country in the world according to United States Census Bureau in 2018. Because of that, there are many variations of hobbies that are owned by Indonesian, inviting the existence of businesses that also vary in meeting the demand for existing hobbies. One of them is PT Sentra Wira Taktikal, a business that sells tactical equipment to people with hobbies like airsoft-gun and shooting.

PT Sentra Wira Taktikal faces several problems, including unvalidated, unrecorded, and poorly process transactions that result in possibility of errors in the receipt of goods, errors in the delivery of goods, etc. These problems make the data cannot be used in the future, thus causing the taken decisions in the decision-making process to be weak. Therefore, PT Sentra Wira Taktikal must implement information systems to assist owners in making decisions.

To achieve the objectives of the study, this study uses qualitative research methods which place more emphasis on aspects of deep understanding of a problem. The analysis technique used is Laudon diagram, which is also supported by other tools such as: Porter 5 Forces for external problem analysis, SWOT for internal problem analysis, $B C B$ for identification of needs, BPMN to describe business processes, User Interface to assist users in accessing the system information, and Decision tree to form logic thinking.

Based on the results of the analysis, the controls produced according to the needs of PT. Sentra Wira Taktikal is a system that is able to define business processes in detail and increase visibility to improve decision making.

Keywords: Information System, Porter 5 Forces, SWOT, User Interface, dan BPMN

\section{PENDAHULUAN}

Negara Indonesia merupakan negara dengan jumlah masyarakat terpadat ke-4 di dunia (United States Census Bureau, 2018), sehingga di dalamnya terdapat banyak hobi yang bervariasi.
Salah satu hobi tersebut adalah taktikal, yaitu hobi yang berisikan kegiatan airsoft-gun, paintball, dll. Taktikal sendiri merupakan hasil turunan dari hobi outdoor activity. Kegiatan tersebut memerlukan peralatan yang khusus, sama seperti peralatan yang digunakan oleh TNI / POLRI. Peralatan 
tersebut sangat memperhatikan segi kualitas, kelengkapan fitur, dan desain. Hobi yang bervariasi akan menciptakan peluang bisnis yang bervariasi pula untuk memenuhi kebutuhankebutuhan yang ada, seperti bisnis taktikal yang berusaha memenuhi kebutuhan hobi taktikal. Bisnis tersebut diuntungkan pula oleh permintaan dari TNI / POLRI yang ingin bersolek lebih dari apa yang sudah disediakan pemerintah. Tidak hanya itu, Pemerintah juga seringkali membeli langsung dalam rangka memberikan starter-kit kepada calon TNI / POLRI, sehingga bisnis taktikal akan selalu memiliki permintaan yang rutin.

Salah satu perusahaan taktikal adalah PT Sentra Wira Taktikal yang terletak di daerah kota Cimahi, PT Sentra Wira Taktikal menjual banyak barang dengan kualitas tinggi, dan sudah memiliki konsumen yang cukup loyal, dari masyarakat umum sampai intansi TNI dan POLRI. Namun, bisnis ini tidak luput dari masalah. Masalah yang kian ditemui berasal dari pencatatan transaksi yang tidak tervalidasi, tercatat, dan tidak terkoordinir dengan baik sehingga adanya kemungkinan timbul kesalahan dalam penerimaan barang, kekeliruan dalam pengiriman barang, dll. Karena hal tersebut, data-data menjadi tidak dapat dipergunakan di kemudian hari, yang mengakibatkan lemahnya keputusan-keputusan yang diambil. Salah satu yang paling krusial ada pada data-data dalam keuangan yang akan berdampak pada seluruh aspek bisnis tersebut.

Masalah-masalah tersebut akan diterjemahkan menjadi tantangan bisnis, sehingga dapat disimpulkan bahwa tantangan bisnis taktikal adalah perlunya peningkatan visibilitas pembuatan keputusan sehingga binis dapat diarahkan sesuai tujuan perusahaan. Jika perusahaan dapat menanggulangi tantangan bisnis tersebut, maka hal tersebut akan memudahkan eksekutif perusahaan ataupun pemilik perusahaan dalam memimpin, mengatur dan mengambil keputusan.

$$
\text { Peningkatan visibilitas pembuatan }
$$

keputusan dapat dicapai dengan menggunakan sistem informasi. Hal ini dikarenakan sistem informasi merupakan alat yang mampu menghadirkan informasi untuk membantu manajer dalam mengambil keputusan di dalam proses bisnis (Laudon \& Laudon, 2016). Adapun untuk menjalankan sistem informasi yang baik, perusahaan perlu memperhatikan ketiga dimensi dalam sistem informasi yaitu manajemen, organisasi dan teknologi. Keterkaitan ketiga dimensi tersebut dalam PT Sentra Wira Taktikal yakni: (1) pihak manajemen perlu memvalidasi data transaksi baik secara internal maupun eksternal, setelah tervalidasi dengan baik maka perlu ada pengelolaan penginputan data secara digital dan terpusat agar semua data yang valid dapat diakses dengan rinci dan dengan waktu yang singkat untuk dianalisa, (2) Perusahaan juga perlu merubah organisasi yaitu dengan melakukan penambahan unit untuk melakukan kegiatan yang dibahas dalam menejemen agar kegiatan tersebut dapat terfokus dan dipertanggungjawabkan, dan (3) Teknologi yang diperlukan adalah teknologi yang mampu mengontrol akses, proses dan manajemen risiko.

Keterkaitan antar-dimensi dalam membangun sistem informasi perlu diperhatikan lebih mendalam guna memberikan solusi binis yang dapat mendefinisikan proses bisnis yang tepat sehingga mampu meningkatkan visibilitas pengambilan keputusan pemilik PT Sentra Wira Taktikal. Adapun tujuan penelitian ini antara lain:

1. Mengetahui kondisi internal dan eksternal PT Sentra Wira Taktikal

2. Mengetahui proses bisnis yang sebaiknya diterapkan untuk mendukung pengambilan keputusan

3. Merancang tampilan yang sesuai dengan kebutuhan perusahaan

Maka dari itu, penelitian ini berjudul "Peningkatan Visibilitas Pengambilan Keputusan Divisi Akuntansi dan Keuangan PT Sentra Wira Taktikal".

\section{KERANGKA TEORI}

\section{Sistem Informasi}

Sistem informasi merupakan instrumen penting untuk membuat nilai dalam perusahaan. Sistem informasi membantu perusahaan dalam meningkatkan pendapatan, atau mengurangi biaya-biaya dengan cara menghadirkan informasi yang membantu manajer dalam mengambil keputusan di dalam proses bisnis. Sistem 
informasi terdiri dari komponen-komponen yang saling berkaitan untuk mengumpulkan, memproses, menyimpan dan mendistribusikan informasi untuk mendukung pengambilan keputusan (Laudon \& Laudon, 2016).

Maka dari itu, sistem informasi berperan untuk memberikan informasi kepada pihak pemilik atau eksekutif yang dapat digunakan untuk membantu pengambilan keputusan sehingga organisasi terkontrol dengan baik (O'Brien, 2010).

Sistem informasi yang dibangun akan efektif bila memperhatikan dimensi-dimensi yang saling terlibat satu sama lain. Hal ini dapat dilihat pada diagram Laudon yang adalah sebuah diagram yang menggambarkan bagaimana unsurunsur manajemen, organisasi dan teknologi bekerja sama untuk menciptakan solusi sistem informasi terhadap tantangan bisnis yang dibahas dalam kasus (Laudon \& Laudon, 2016). Diagram Laudon dipakai pada kegiatan sistem analisis karena berguna dalam menjabarkan keseluruh mengapa suatu sistem informasi diperlukan dilihat dari sisi manajemen, organisasi, dan teknologi.

Manajemen dalam diagram Laudon menggambarkan kondisi dan tantangan yang dihadapi oleh perusahaan, serta rancangan strategi tindak lanjut untuk menghadapi masalah dan tantangan yang ada. Sementara itu, Organisasi merupakan struktur formal organisasi yang terdiri dari berbagai tingkatan dan spesialisasi. Terakhir, Teknologi merupakan alat yang digunakan untuk menunjang perubahan yang terjadi di dalam organisasi (Laudon \& Laudon, 2016).

Sistem informasi memilki beberapa jenis yang mengacu pada tingkatan manajerial yang berbeda, adapun jenis sistem informasi yang dimaksud :

\section{Transaction Process System (TPS)}

Pada suatu perusahaan diperlukan adanya pencatatan aktivitas dan pencatatan transaksi - transaksi yang dilakukan oleh perusahaan, seperti penjualan barang, pembelian barang, beban perusahaan, dll. TPS merupakan jenis informasi yang akan menyediakan informasi - informasi tersebut, karen TPS merupakan pencatatan berbasis sistem informasi yang mencatat secara rutin untuk mendukung jalannya bisnis (Laudon \& Laudon, 2016).

TPS diperlukan oleh pemilik / eksekutif untuk memonitor internal operasi perusahaan dan hubungan perusahaan dengan lingkungan eksternal terkait. TPS melakukan pencatatan data transaksi bisnis, mengupdate basis data, dan menghasilkan dokumen bisnis (O'Brien, 2010).

Berdasarkan hal tersebut, dapat disimpulkan bahwa TPS membantu perusahaan untuk menyimpan catatan aktivitas dan transaksi rutin sehingga akan memudahkan pemilik dan atau pihak eksekutif dalam menelurusi informasi yang dibutuhkan

Karena itu TPS merupakan dasar dari bisnis, sehingga jika TPS mengalami gangguan maka proses bisnis akan menjadi kacau tidak dalam internal perusahaan saja namun pada perusahaan terkait lainnya.

\section{Management Information System (MIS)}

MIS merupakan sistem informasi untuk digunakan oleh middle management. MIS digunakan oleh manajemen tingkat tengah untuk mengawasi, mengendalikan bisnis dan memprediksi kinerja di masa depan. MIS membutuhkan data yang dihasilkan oleh TPS, dengan memakai data dari TPS maka MIS dapat menyajikan kinerja perusahaan pada masa lalu, masa kini, dan masa yang akan datang (Laudon \& Laudon, 2016).

MIS menyediakan informasi dalam bentuk laporan dan tampilan-tampilan yang digunakan oleh pemilik / eksekutif pereusahaan. Informasi yang disediakan oleh MIS juga digunakan untuk mendukung pengambilan keputusan. MIS sebagai sistem berbasis komputer yang menyediakan informasi untuk menjelaskan perusahaan atau salah satu sistem utamanya dilihat dari yang terjadi di masa lalu, yang terjadi sekarang, dan yang kemungkinan akan terjadi di masa depan (O'Brien, 2010).

Beberapa manfaat Sistem Informasi Manajemen (O'Brien, 2010) :

- Menghasilkan informasi yang dapat membantu para manajer untuk mengambil keputsan rutin. 
- Menampilkan informasi yang dibutuhkan oleh pembuat keputusan dalam bentuk laporan, display pada layar monitor, dan jawaban atas pertanyaan.

Jadi MIS adalah sitem informasi yang menggunakan data TPS dan digunakan oleh manajemen tingkat menengah yang berupa laporan untuk mengawasi, mengendalikan bisnis, memprediksi kinerja di masa depan, dan mendukung pengambilan keputusan.

Penelitian ini berfokus pada perancangan sistem TPS yang berfungsi untuk membantu PT Sentra Wira Taktikal mencatat dokumen formal secara terpusat, serta sistem MIS yang membantu perusahaan dalam mengolah data TPS seperti pada tampilan Dashboard.

\section{Porter 5 Forces}

Menurut Laudon \& Laudon (2016), strategi tidak dtentukan oleh kompetisi dengan pesaing langsung saja, namun juga oleh empat kekuatan lain di lingkungan industri: pendatang pasar baru, produk pengganti, pelanggan, dan pemasok. Porter 5 Forces dipakai pada penelitian ini untuk menganalisis aktivitas eksternal yang akan berpengaruh pada bisnis taktikal. Efek tersebut dilihat dari sudut pandang yang sesuai dari pendapat Laudon, yaitu pesaing yang ada pada bisnis taktikal terutama pada toko taktikal di Indonesia. Produk pengganti adalah ancaman dari substitusi produk yang dijual oleh PT Sentra Wira Taktikal. Pelanggan membahas mengenai seberapa loyal dan kerelaan pelanggan dalam membeli dengan harga yang ditentukan. Pemasok, membahas ketergantungan PT Sentra Wira Taktikal terhadap pemasoknya, jumlah pemasok yang ada, dan pelayanan yang diberikan pemasok.

\section{SWOT}

Analisis SWOT merupakan salah satu alat untuk menganalisis kekuatan (strength) dan kelemahan (weakness) perusahaan, peluang pasar (market opportunities), dan ancaman eksternal (external threats) yang akan mempengaruhi keberlangsungan perusahaan (Thompson, Peteraf, Gamble, \& Strickland III, 2016). Analisis SWOT yang baik memberikan dasar untuk membuat strategi yang mengkapitalisasi kekuatan sumber daya perusahaan, mengatasi kelemahan sumber daya, mengambil peluang terbaik yang bisa diraih perusahaan, dan melawan ancaman yang dapat menghancurkan masa depan perusahaan. Analisis SWOT merupakan alat bantu dalam menciptakan strategi-strategi dari hasil penggabungan aspek eksternal dan juga internal perusahaan.

\section{Strategic Business Objectives}

Pada sistem, ada suatu keadaan salaing ketergantungan antara sistem informasi suatu perusahaan dan kempuan perusahaan itu sendiri. Perubahan di dalam strategi, peraturan, dan proses bisnis menyebabkan adanya perubahan di dalam hardware, software, database, dan telekomunikasi seperti ditunjukkan pada gambar 1. Seringkali, apa yang organisasi ingin lakukan tergantung pada apakah sistem yang dimiliki mampu menjalakan kegiatan tersebut (Laudon \& Laudon, 2016).

Strategi bisnis objektif pada penelitian ini berguna dalam menentukan solusi bisnis dari permasalahan yang ada di PT Sentra Wira Taktikal. Sehingga akhirnya tantangan bisnis dapat teratasi oleh bantuan strategi bisnis objektif yang didasari sistem informasi. Menurut Laudon \& Laudon (2016) ada 6 jenis strategi bisnis objektif yaitu: (1) Operational Excellence, (2) New Products, Services, and Business, (3) Customer and Supplier Intimacy, (4) Improved Decision Making, (5) Competitive Advantage,dan (6) Survival.

Strategi yang tepat bagi PT Sentra Wira Taktikal adalah Operational Excellence. Strategi Operational Excellence bertujuan agar perusahaan dapat meningkatkan efisiensi proses operasionalnya sehingga dapat memperoleh profit yang lebih tinggi. Sistem informasi dan teknologi merupakan alat yang sangat penting untuk mengelola hal tersebut, terlebih disaat adanya beberapa perubahan di dalam praktik dan perilaku bisnis. Efisiensi proses bisnis yang dipengaruhi oleh sistem informasi di dalam penelitian ini adalah perusahaan dapat lebih cepat dalam melakukan pencatatan sehingga semua data dapat terkumpul (tidak ada data yang hilang) serta memastikan semua transaksi tercatat dengan baik. 


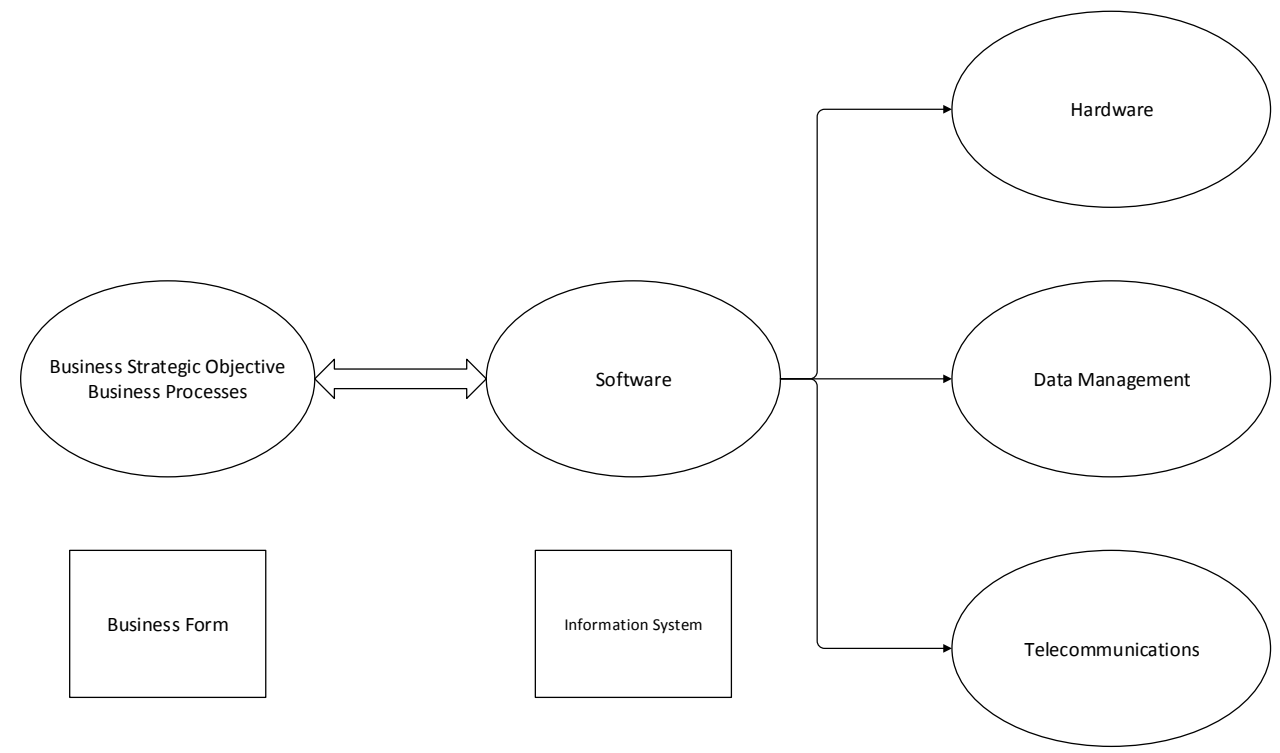

Gambar 1. Keterkaitan Organisasi dan Sistem Informasi

\section{Business Challenge Bundle (BCB)}

Framework BCB digunakan dalam rangka memetakan penyebab dari permasalahan dan memprioritaskan masalah yang harus ditangani terlebih dahulu (Gunawan, 2012). Peran BCB adalah memetakan tujuan yang hendak dituju dan apa saja yang harus dilakukan perusahaan untuk mencapai tujuan tersebut. Dengan itu akan terlihat masalah-masalah yang ada saat hendak mencapai tujuan tersebut. BCB juga akan memperlihatkan data-data terkait yang harus ada untuk meraih tujuan perusahaan. Dalam kata lain BCB merupakan proses dalam mengidentifikasi kebutuhan untuk mencapai tujuan perusahaan.

\section{Business Process Model Notation (BPMN)}

BPMN merupakan aplikasi untuk mendukung suatu bisnis di mana penggunanya dapat menggambarkan keseluruhan proses bisnis yang mencangkup fungsi-fungsi dalam bisnis, sistem perusahaan, dan batasan-batasan dalam organisasi (Stiehl, 2014). BPMN dipakai sebagai alat untuk menggambarkan proses usulan agar tujuan perusahaan dapat tercapai dengan mudah. Di sisi lain, penggambaran proses juga dilakukan dalam rangka memudahkan pemilik atau eksekutif melihat lebih rinci adanya fungsi-fungsi bisnis, sistem, dan batasan-batasan tertentu.

\section{Tampilan Pengguna}

Setiap teknologi informasi memiliki interface atau antarmuka yang berfungsi untuk menjembatani antara pengguna dengan teknologi itu sendiri. Teknologi informasi yang satu dengan yang lain memiliki desain interface yang berbedabeda sesuai dengan fungsi dan kebutuhan penggunanya. Misalnya, teknologi yang digunakan oleh seorang dokter dengan kebutuhannya untuk memberikan diagnosis kepada pasien akan berbeda dengan teknologi informasi yang digunakan oleh seorang manajer dalam menentukan strategi pada perusahaannya (Shneiderman \& Plasant, 2005).

\section{Decision Tree}

Pohon Keputusan atau dikenal dengan Decision Tree adalah salah satu metode klasifikasi yang menggunakan representasi suatu struktur pohon yang yang berisi alternatif-alternatif untuk pemecahan suatu masalah. Pohon ini juga menunjukkan faktor-faktor yang mempengaruhi hasil alternatif dari keputusan tersebut disertai dengan estimasi hasil akhir bila kita mengambil keputusan tersebut. Peranan pohon keputusan ini adalah sebagai Decision Support Tool untuk membantu manusia dalam mengambil suatu keputusan (Tsang, Kao, Yip, Wai, \& Dan Lee, 2009).

Penelitian ini menggunakan Decision tree untuk meningkatkan pengambilan keputusan perusahaan terkait pengaturan keuangan. Hal ini menjadikan pengambilan keputusan dapat menghasilkan logika berpikir untuk pemilik ataupun eksekutif dalam menentukan keputusan 
yang berkaitan dengan keluar dan masuknya uang perusahaan.

\section{METODE PENELITIAN}

\section{Jenis Penelitian}

Penelitian ini menggunakan jenis penelitian deskriptif analisis dengan tujuan untuk menggambarkan proses bisnis, tidak hanya untuk menjelaskan secara menyeluruh masalah yang akan diteliti dan diamati saja, namun juga akan menganalisis keperluan perusahaan sesuai dengan tujuan penelitian (Sugiyono, 2014). Penelitian ini berusaha untuk menghasilkan sebuah rancangan sistem keuangan yang dapat membantu pengelolaan uang dalam kegiatan membeli dan menjual di dalam perusahaan PT Sentra Wira Taktikal. Peneliti memakai beberapa alat untuk menganalisis dan membuat usulan yaitu: Diagram Laudon, Porter 5 Forces, SWOT, BCB, BPMN, tampilan pengguna, dan decision tree. Alat analisis tersebut akan dibahas secara mendetil di bagian selanjutnya.

\section{Metode Penelitian}

Penelitian ini menggunakan metode studi kasus yang berfokus pada objek penelitian yaitu PT Sentra Wira Taktikal (Yin, 2011).

Studi kasus digunakan sebagai suatu penjelasan komprehensif yang berkaitan dengan berbagai aspek seseorang, suatu kelompok, suatu organisasi, suatu program, atau suatu situasi kemasyarakatan yang diteliti, diupayakan dan ditelaah sedalam mungkin. Studi kasus memiliki pengertian berkaitan dengan penelitian yang terperinci tentang seseorang atau unit sosial dalam jangka waktu tertentu (Yin, 2011).Penelitian studi kasus dilakukan ketika topik penelitian luas, kompleks dan tidak terdapat banyak teori yang tersedia walaupun konteks tersebut penting (Dul \& Hak, 2008)

Penelitian ini akan mendeskripsikan dan menganalisis secara mendalam kondisi dan kendala yang dihadapi oleh divisi akutansi dan keuangan serta menyelesaikan masalah sistem keuangan PT Sentra Wira Taktikal (Creswell, 2007).

\section{Uji Keabsahan \\ Validitas Data}

Suatu penelitian dapat dinyatakan valid apabila data yang dikumpulkan sesuai dengan tujuan penelitian dan diinterpretasikan secara benar (Yin, 2011). Berdasarkan 7 strategi uji validitas yang dikemukakan oleh Yin (2011), penelitian ini menggunakan strategi Intensive Long- Term (field) Involvement dan Triangulation. Strategi Intensive Long- Term (field) Involvement digunakan untuk memperoleh pemahaman sepenuhnya dan mendalam tentang kegiatan yang terjadi di lapangan, dan dengan maksud mendapatkan kesempatan untuk melakukan pengamatan dan wawancara berulang. Strategi triangulation juga digunakan uuntuk menghimpun fakta-fakta yang terjadi dari berbagai sumber informan. Di samping itu, hasil penelitian akan dicek kembali dengan menanyakan tanggapan dari pemilik mengenai rancangan sistem yang dibuat.

\section{Uji Reliabilitas}

Menurut Sugiyono, teknik pengumpulan data triangulasi terdiri dari tiga cara yaitu triangulasi teknik, sumber data, dan waktu (Sugiyono, 2014). Penelitian ini menggunakan triangulasi sumber data. Triangulasi sumber data dilakukan dengan mengumpulkan data dari berbagai sumber berbeda, antara lain: wawancara dengan pemilik perusahaan, observasi ke perusahaan PT Sentra Wira Taktikal, studi dokumen dengan mengamati dokumen perusahaan saat ini, serta studi literatur yang berasal dari buku atau jurnal terkait pengembangan sistem informasi.

\section{Metode Pengumpulan Data}

Data berfungsi sebagai dasar dalam penelitian. Dalam penelitian kualitatif, data yang relevan berasal dari 4 kegiatan: interviewing, observing, collecting, dan examining (Yin, 2011).

\section{- Interviewing.}

Metode wawancara dalam penelitian ini adalah wawancara kualitatif, yang merupakan wawancara spontan tanpa mempersiapkan pertanyaan terlebih dahulu. Pertanyaanpertanyaan yang digunakan lebih bersifat 
terbuka karena metode ini lebih mengedepankan pembicaraan dengan cara membangun hubungan sosial mereka sehingga terjadi interaksi dua arah antara pewawancara dengan narasumber. Dalam penelitian ini, peneliti hanya mewawancarai Bapak Asep Purnawan sebagai narasumber sekaligus pemilik perusahaan.

- Observing.

Observasi non-partisipan digunakan dengan mengamati dan mencatat hal-hal yang berkaitan dengan tujuan penelitan. Fokus observasi pada penelitian ini adalah pada proses bisnis perusahaan.

- Collecting.

Pengambilan data dilakukan dengan mengambil data-data dari buku, jurnal, wawancara, pengamatan ke lokasi, penelitian serupa dan internet.

\section{- Examining.}

Pada penelitian ini data-data yang ada diuji melalui beberapa sumber, seperti: literature review, studi dokumen, dan menanyakan kembali kepada pemilik.

\section{Sistem Analisis}

Sistem analisis adalah langkah-langkah untuk menganalisis masalah sistem informasi di dalam perusahaan. Sistem analisis membuat kerangka berpikir dari sistem yang sudah ada, dan mengidentifikasi masalah yang ada di dalamnya berdasarkan uji dokumen, lembar kerja, dan prosedur sehingga tercapai solusi dengan membuat sistem baru atau memperbaiki sistem yang ada (Laudon \& Laudon, 2016).

Analisis lingkungan eksternal dan internal PT Sentra Wira Taktikal dilakukan guna mengetahui kondisi ekternal dan internal perusahaan, sehingga dapat menghasilkan sistem informasi yang sesuai dengan kebutuhan perusahaan. Sistem analisis dalam penelitian ini menggunakan kerangka kerja Porter 5 Forces, SWOT, dan Business Challenge Bundle. Porter 5 Forces digunakan untuk menganalisis faktor industri yang mempengaruhi perusahaan. Hasil analisis Porter 5 Forces tersebut selanjutnya digunakan sebagai fakta eksternal yang akan digunakan di dalam analisis SWOT. Analisis SWOT digunakan untuk menilai kondisi internal dan eksternal perusahaan serta menentukan strategi yang dapat mengatasi dan mendukung kondisi yang ada. Terakhir, setelah strategi ditentukan, akan dilajutkan dengan analisis menggunakan business challenge bundle (BCB) untuk menentukan penyebab dari masalah ataupun kebutuhan dari tujuan yang hendak dicapai.

\section{Sistem Desain}

Di dalam proses pengembangan sistem, sistem desain bertujuan untuk menyajikan keseluruhan rencana atau model sistem (Laudon \& Laudon, 2016). Setelah mengetahui kondisi dan hal-hal apa saja yang diperlukan untuk membangun sistem yang sesuai dengan keperluan perusahaan, selanjutnya akan digambarkan proses bisnis yang baru untuk mencapai tujuan yang hendak dicapai (tujuan dari BCB) dengan menggunakan BPMN (Business Process Model Notation). Untuk mendukung proses dengan memanfaatkan teknologi digital dibuatlah tampilan pengguna yang memudahkan pengguna untuk memperoleh informasi yang diperlukan. Terakhir, Decision Tree digunakan untuk meningkatkan pengambilan keputusan perusahaan terkait pengaturan keuangan.

\section{HASIL DAN PEMBAHASAN}

\section{Proses Bisnis Aktual}

Saat ini PT. Sentra Wira Taktikal memiliki 2 macam took yaitu toko fisik dan toko online. Toko fisik PT. Sentra Wira Taktikal beroperasi pada pukul 12.00 sampai pukul 18.00. Sedang toko online beroperasi 24 jam. Toko online yang dikelola oleh PT. Sentra Wira Taktikal antara lain : Facebook, Kaskus, Tokopedia, dan Bulakapak. Rata - rata transaksi PT Sentra Wira Taktikal per hari adalah 10 transaksi yang didominasi oleh transaksi online. 


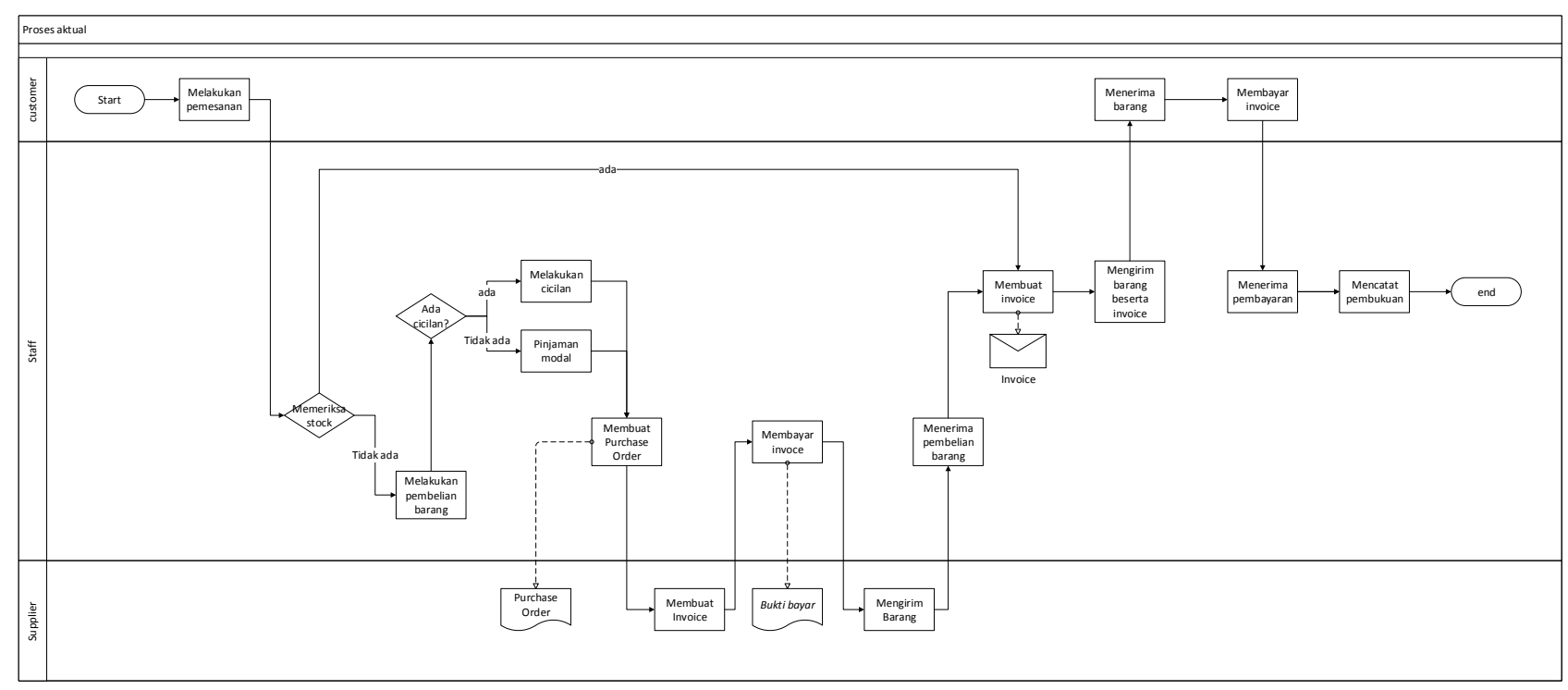

Gambar 2. Proses Bisnis Aktual

Kegiatan yang dilakukan di toko fisik adalah konsumen datang untuk melihat display barang, memilih produk yang akan dibeli atau memesannya ke staf (jika tidak tersedia di display) dan melakukan transaksi sesuai yang disediakan oleh PT Sentra Wira Taktikal yaitu cash dan mesin EDC. Pesanan secara online memiliki proses yang serupa di mana konsumen dapat memilih barang yang diinginkan ataupun menanyakannya secara online (jika tidak tersedia) lalu barang akan dikirim melalui JNE setelah konsumen berhasil melakukan transaksi pembayaran. Pencatatan transaksi selama ini dilakukan secara manual dengan mengumpulkan dokumen formal lalu diinput ke dalam Microsoft Excel. Akan tetapi, perusahaan mengalami kendala di mana dokumen formal yang dimiliki perusahaan belum lengkap sehingga tidak mencatat (record) seluruh data yang dibutuhkan untuk pengambilan keputusan. Di samping itu, beberapa transaksi tidak tercatat dikarenakan human error.

Pada gambar 1 dapat dilihat bahwa PT Sentra Wira Taktikal belum memiliki divisi yang spesifik sehingga staf memiliki akses yang cukup besar dalam mengendalikan bisnis baik prosedur penjualan maupun pembelian. Dapat terlihat juga bahwa pada proses bisnis yang ada saat ini tidak ada penyimpanan data yang baik secara formal. Adapun data yang dihasilkan hanya berupa purchase order dan invoice, sehingga data yang ada belum bisa dikatakan valid. Perusahaan juga belum memiliki sistem informasi dalam mengumpulkan data sehingga data yang ada tidak dapat dipantau oleh pemilik secara efektif maupun efIsien. Hal tersebut dapat menimbulkan potensi kecurangan ataupun error dalam mengelola penjualan ataupun pembelian.

Proses yang ada bergerak hanya berdasarkan permintaan konsumen, dan dari hasil wawancara, pemilik mengambil keputusan hanya berdasarkan cocok dengan selera. Hal ini menimbulkan potensi kelebihan atau kekurangan di bagian pembelian yang akan berefek pada keuangan perusahaan.

\section{Diagram Laudon}

Diagram Laudon merupakan alat yang menyatukan keseluruhan mengapa alat-alat dalam pembahasan dipakai. Diagram Laudon untuk PT Sentra Wira Taktikal ditunjukkan seperti pada gambar 2. Dalam diagram Laudon pada bagian tantangan bisnis berisikan masalah dalam PT Sentra Wira Taktikal. Masalah yang ada didapatkan melalui observasi, wawancara, dan pengumpulan data pada waktu dan sumber yang berbeda-beda. Analisis yang dilakukan dibantu dengan analisis Porter 5's Forces untuk bagian eksternal dan analisis SWOT untuk bagian internal. 
Permasalahan yang ada dikelompokkan ke dalam tiga bagian dimensi sistem informasi yaitu: Manajemen, Organisasi, dan Teknologi.

Pada bagian manajemen terdapat permasalahan data yang tidak tervalidasi, tidak ada penyimpanan secara digital dan terpusat, dan pembuatan keputusan yang tidak didasari datadata. Seperti yang dikemukakan sebelumnya, dimana banyak keputusan yang diambil berdasarkan selera pemilik sehingga pengambilan keputusan tidak bersifat objektif dan cenderung subjektif. Masalah-masalah tersebut terlihat jelas pada saat penggabungan data eksternal dan internal perusahaan (analisis SWOT).

Di samping itu, perusahaan belum memiliki standard operating procedur (SOP) yang jelas sehingga diperlukan SOP tersebut untuk memastikan setiap proses (seperti pengumpulan data) dan pengambilan keputusan berdasarkan standard yang telah ditentukan sebelumnya.

Pada bagian organisasi, masalah yang ditemukan adalah tidak adanya divisi khusus untuk menangani masalah. Masalah tersebut tersebut terlihat jelas ketika melihat gambaran proses bisnis yang didominasi oleh divisi staff saja yang menimbulkan potensi kesalahan yang dilakukan cukup besar karena tidak adanya divisi yang saling memeriksa. Oleh karena itu, solusi untuk masalah pada bagian organisasi adalah perusahaan perlu mengelompokkan pegawainya ke dalam divisi tertentu sehingga terbentuk peran dan tanggung jawab khusus bagi masing-masing pegawai. Adapun divisi yang perlu dibentuk adalah divisi pembelian, penjualan, dan keuangan. Divisi pembelian bertanggung jawab atas proses pembelian PT Sentra Wira Taktikal dan hubungannya dengan pemasok. Divisi penjualan memiliki peran untuk melaksanakan proses penjualan (seperti pencatatan dan transaksi penjualan) dan meningkatkan pelayanan kepada konsumen. Sedangkan divisi keuangan berperan untuk memastikan bahwa transaksi penjualan dan pembelian valid (terdapat bukti yang jelas dan memadai). Penelitian ini berfokus pada divisi keuangan yang berperan untuk memastikan setiap transaksi PT Sentra Wira Taktikal berjalan dengan baik.
Masalah pada bagian teknologi adalah kurangnya pemanfaatan sistem informasi sehingga kurangnya proses kontrol dan akses yang bisa dilakukan oleh siapa saja yang menyebabkan risiko bisnis yang tinggi dari internal sendiri dan terlebih dari ekternal perusahaan.

Karena itu, PT Sentra Wira Taktikal memerlukan sistem informasi yang membatasi akses untuk proses-proses tertentu (mengacu pada divisi yang dibentuk pada dimensi organisasi), sehingga sistem hanya dapat diakses oleh pihak yang berwenang. Selain itu, perusahaan memerlukan sistem di mana prosedur yang dilakukan oleh karyawannya dapat terbaca (tracking) bila mengacu pada sistem informasi tersebut. Contoh kasus : jika bagian penjualan sudah membuat sales order namun bagian keuangan tidak juga menerbitkan invoice. Hal ini bisa disebabkan antara lain oleh 2 hal, pertama : adanya kekurangan data yang diterima oleh bagian keuangan untuk melakukan cross-check data misalnya : tidak ada packing list untuk Sales Order tersebut. Dapat disimpulkan kesalahan dilakukan oleh divisi penjualan atau gudang karena belum adanya packing list dari gudang (bisa terjadi karena penjualan belum atau tidak terjadi). Kedua, bila surat packing dan sales order surat dilakukan, namun bagian keuangan belum juga menerbitkan invoice berarti bagian keuangan telah lalai melakukan tugasnya. Bila melihat contoh kasus di atas, sistem informasi dapat digunakan sebagai alat untuk mengontrol proses di dalam persuahaan.

Berdasarkan penejalasan di atas, PT Sentra Wira Taktikal memerlukan Management Control System dalam menanggulangi permasalahan yang ada sehingga solusi bisnis akan tercipta yaitu pendefinisisan proses bisnis dan peningkatan visibilitas untuk pengambilan keputusan.

Adapun management control system yang dimaksudkan di sini adalah sistem informasi yang memiliki fitur untuk memvalidasi data atau informasi yang masuk ke dalam sistem, melakukan pengumpulan data secara terpusat dan berbasis digital sehingga memudahkan pemilik dan atau eksekutif dalam mengakses data tersebut. 


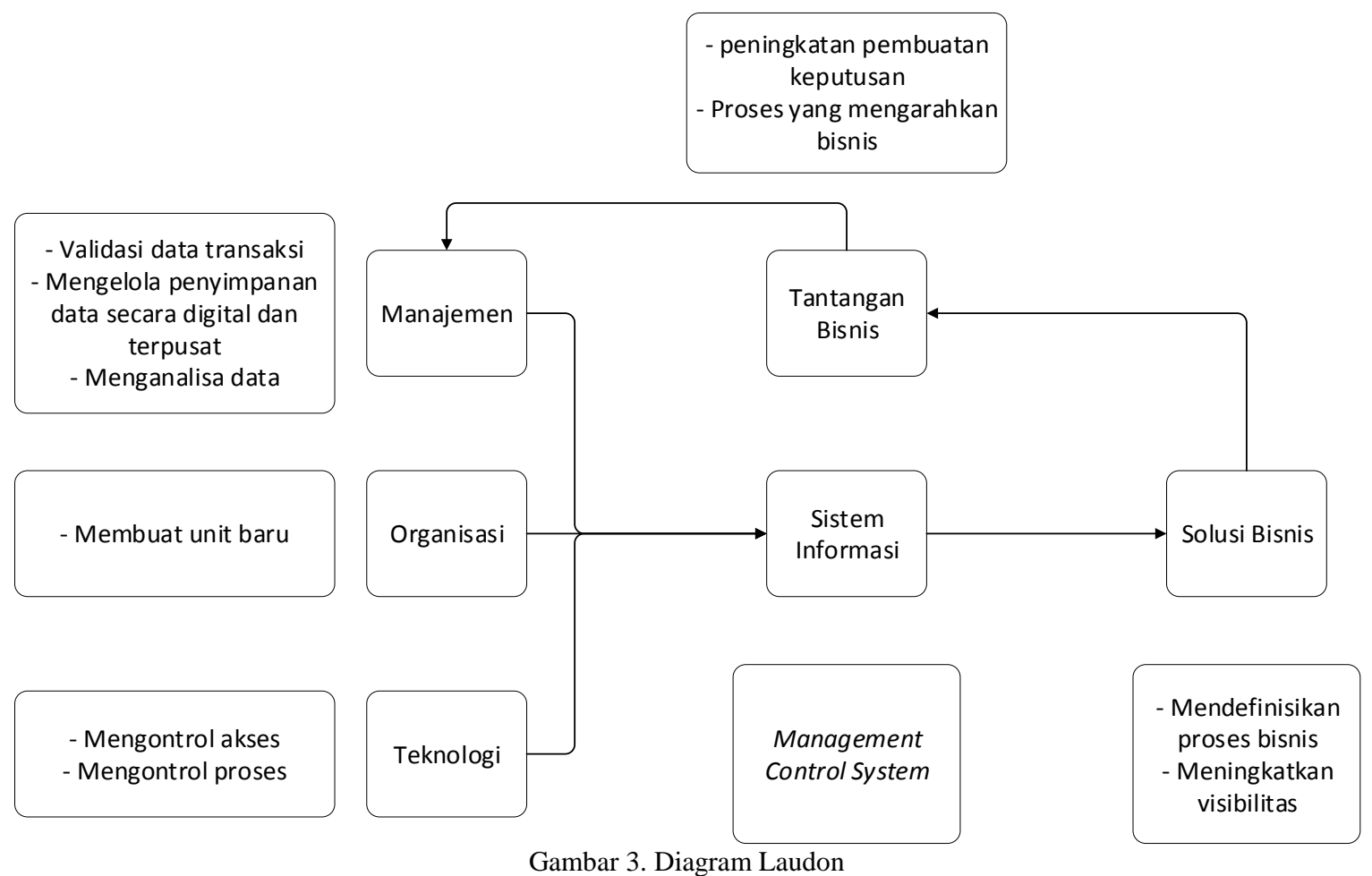

\section{Tantangan dan Peluang}

Tantangan dan peluang yang dihadapi oleh perusahaan dijabarkan dengan menggunakan kerangka Porter 5's Forces, adapun penjelasannya seperti berikut ini :

\section{Persaingan dalam Industri}

Bisnis taktikal tidak memiliki pesaing yang banyak karena adanya kesulitan dalam memasuki bisnis ini terkait modal dan pengetahuan. Terutama ketika membandingkan segmentasi pasar, ada beberapa toko yang menjual produk taktikal dengan pasar di level bawah. Sedangkan PT Sentra Wira Taktikal memiliki segmentasi pasar yang mementingkan kualitas, desain, dan fitur sehingga konsumennya berada pada level yang lebih atas, sehingga persaingan bisnis taktikal di Indonesia untuk PT. Sentra Wira Taktikal tidak keruh.

Di samping itu, PT Sentra Wira Taktikal sudah menjadi pemasok bagi instansi militer yang membuktikan bahwa eksistensinya di industri ini cukup tinggi dan sulit tergantikan di samping produk yang ditawarkan adalah produk dengan kualitas baik.

\section{Pemasok}

Umumnya PT Sentra Wira Taktikal melakukan impor barang dari pemasok luar negeri. Hal ini menyebabkan PT Sentra Wira
Taktikal sangat bergantung pada kondisi Negara di mana bila kondisi Negara tidak kondusif sehingga menyebabkan nilai rupiah melemah, perusahaan mengalami kendala di mana terjadi peningkatan harga beli juga kendala importer seperti sulitnya menerima barang impor.

PT Sentra Wira Taktikal memiliki ketergantungan yang tinggi pada pemasok disebabkan sulitnya mencari pemasok yang dapat menghadirkan barang sesuai kriteria yang PT Sentra Wira Taktikal inginkan, walaupun sudah menjadi pelanggan yang setia, PT Sentra Wira Taktikal tidak merasakan adanya pelayanan yang cukup berarti. Karena sedikitnya jumlah pemasok produk taktikal menyebabkan harga barang di masing-masing pemasok tidak memiliki perbedaan harga yang signifikan.

3. Ancaman Pendatang Baru

Berdasarkan wawancara dengan pemilik PT Sentra Wira Taktikal, saat ini tingkat ancaman pendatang baru tergolong rendah. Hal ini dipengaruhi oleh sulitnya pendatang baru untuk memasuki industri ini karena modal yang dibutuhkan besar dan pengetahuan akan produk-produk taktikal gear harus tinggi. Di samping itu, untuk bertahan di industri ini, perusahaan memerlukan koneksi yang tinggi 
dengan instansi militer atau komunitas hobi tertentu.

\section{Ancaman Produk Substitusi}

PT Sentra Wira Taktikal menawarkan perlengkapan taktikal. Produk yang dapat menjadi subtitusi dari produk-produk taktikal yaitu perlengkapan outdoor yang memiliki fungsi yang mirip dengan produk taktikal seperti sepatu gunung, kacamata olahraga, dll. Namun terdapat perbedaan kualitas antara perlengkapan taktikal dengan perlengkapan outdoor. Perlengkapan taktikal memiliki kualitas, desain dan fitur yang lebih baik daripada perlengkapan outdoor lain karena perlengkapan taktikal banyak digunakan untuk instansi militer sebagai sarana penunjang profesi mereka, sehingga produk taktikal harus memiliki tingkat daya tahan, kenyamanan, fitur yang tinggi. Akan tetapi ada beberapa konsumen yang lebih memperhatikan harga produk sehingga lebih memilih untuk menggunakan produk subtitusi yaitu perlengkapan outdoor.

\section{Konsumen}

Jumlah konsumen PT. Sentra Wira Taktikal tergolong sedikit karena produk yang ditawarkan merupakan produk untuk menunjang hobi tertentu. Selain itu harga yang ditawarkan perusahaan tergolong mahal. Namun dengan keterbatasan tersebut, konsumen yang dimiliki PT. Sentra Wira Taktikal, memiliki loyalitas yang cukup tinggi dan tidak mempermasalahkan harga barang asalkan perusahaan tetap menyediakan produk secara lengkap karena konsumen akan mencari cara untuk mendapatkan produk dengan kualitas yang tinggi, desain yang menarik, dan fitur yang lengkap berapapun harganya di penjual lain.

Selain itu, PT Sentra Wira Taktikal sudah terbiasa menjadi pemasok rutin bagi instansi militer yang menyebabkan perusahaan memiliki konsumen tetap untuk produknya dan dapat membuktikan bahwa produk yang ditawarkannya merupakan produk dengan kualitas unggul.

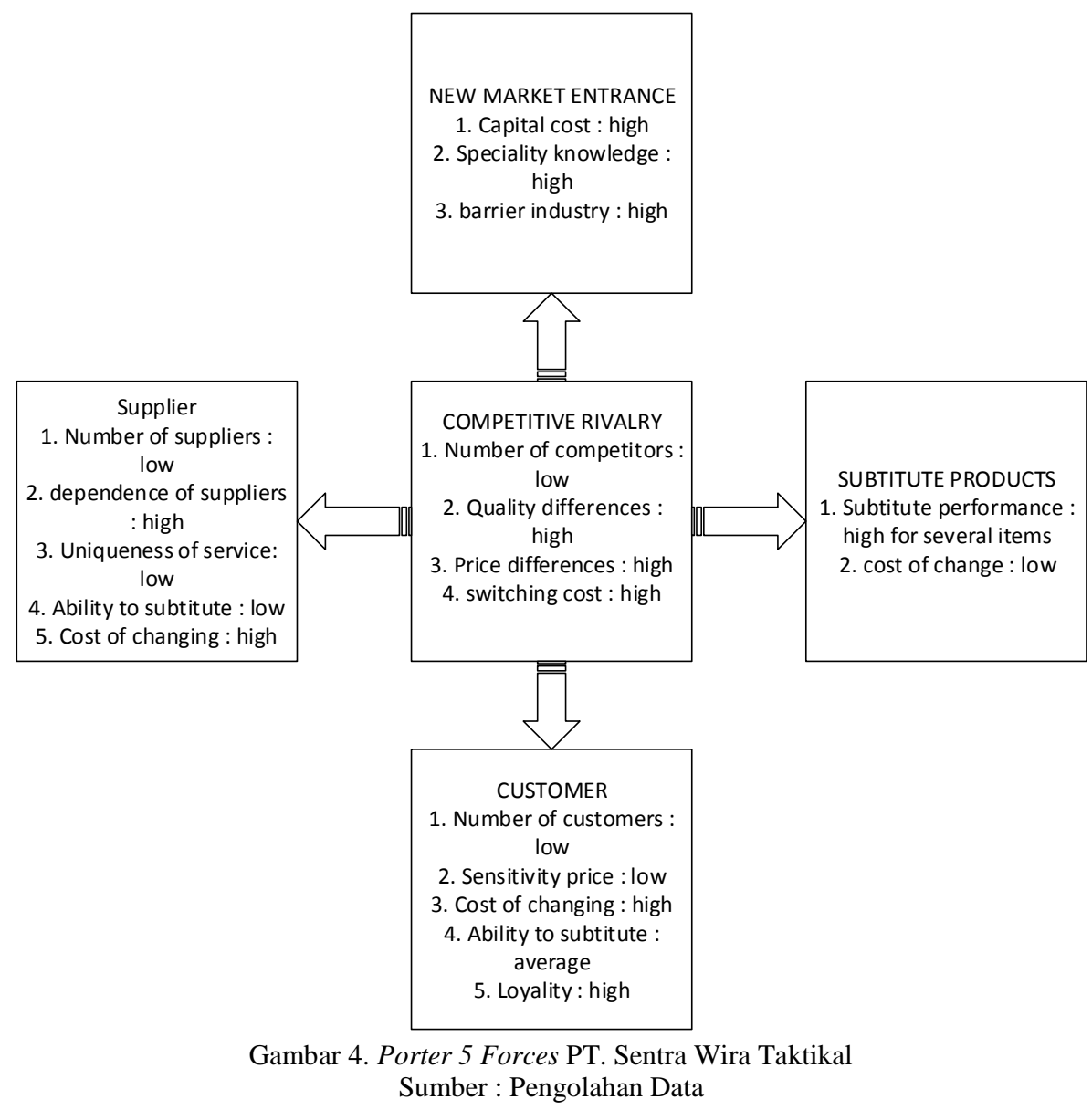




\section{Strategi untuk Mengatasi Masalah Internal dan Eksternal}

Analisis SWOT seperti gambar 3 dipakai untuk menghadirkan strategi-strategi untuk menyikapi masalah yang ada dari luar perusahaan maupun permasalahan di dalam perusahaan dengan kekuatan yang dimiliki dan kesempatan yang tercipta di lingkungan. Poin threat dan opportunity diambil dari alat sebelumnya yaitu Porter 5 forces. Ada 4 strategi yanag dihasilkan melalui analisis SWOT ini yaitu:

1. S -> O: memvalidasi data transaksi yang lebih rinci untuk pengawasan atau kontrol internal.

Walaupun PT Sentra Wira Taktikal sudah memiliki brand yang dikenal secara luas dan adanya peluang dari berbagai intansi (seperti TNI / Polri) membeli produknya, tidak berarti perusahaan mengesampingkan pencatatan keluar dan masuknya barang. Karena walaupun barang laris terjual, dokumen-dokumen tetap harus dibuat dan diberikan atau diarsipkan sebagai laporan tertulisnya, sehingga celahcelah kehilangan barang, salah kirim, dan kekeliruan harga dapat dihindari.

2. W $\rightarrow$ O: Mengelola penyimpanan data secara digital.
Melanjutkan dari strategi pertama, data-data yang dibuat oleh perusahaan harus diarsipkan, dengan sistem informasi pengarsipan tersebut menjadi pengarsipan secara digital. Setiap dokumen formal harus dimasukan ke dalam sistem. Hal ini membantu perusahaan agar data yang dimiliki perusahaan tidak tercecer, dan efisiensi dalam tracking data karena semua data terkumpul secara terpusat.

Melihat dari sisi eksternal yaitu adanya teknologi yang sedang berkembang, maka perusahaan memiliki kesempatan dalam membuat pembukuan yang tidak maksimal tersebut menjadi pembukuan yang berbasis teknologi.

Strategi ini berguna untuk memudahkan pemilik dan atau pihak eksekutif memeriksa dokumen-dokumen tersebut karena sudah dalam bentuk database dan dokumen-dokumen tersebut dapat diakses kapanpun. Tidak hanya itu, digitalisasi dokumen tersebut menjadi aspek penting untuk pengolahan data sehingga perusahaan dapat memperoleh informasi (laporan) yang dapat digunakan untuk meningkatkan efektivitas dan efisiensi pengambilan keputusan. 
Strenght:

1. Memiliki Modal tinggi

2. Brand sudah terkenal

3. Memiliki toko fisik

4.Sudah menjadi Perseroan Terbatas. yang lebih rinci untuk

4. Rutinnya kebutuhan dari TNI/POLRI terhadap produk.

5. Teknologi sedang berkembang pesat

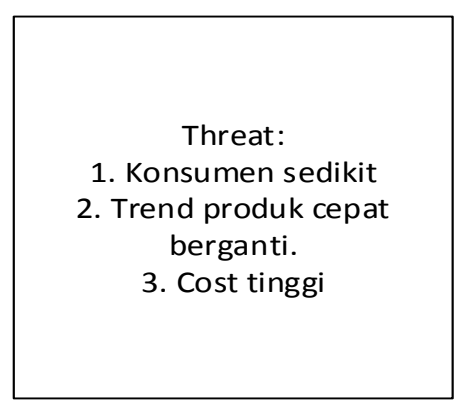

S1->04

Memvalidasi data transaksi pengawasan / kontrol internal
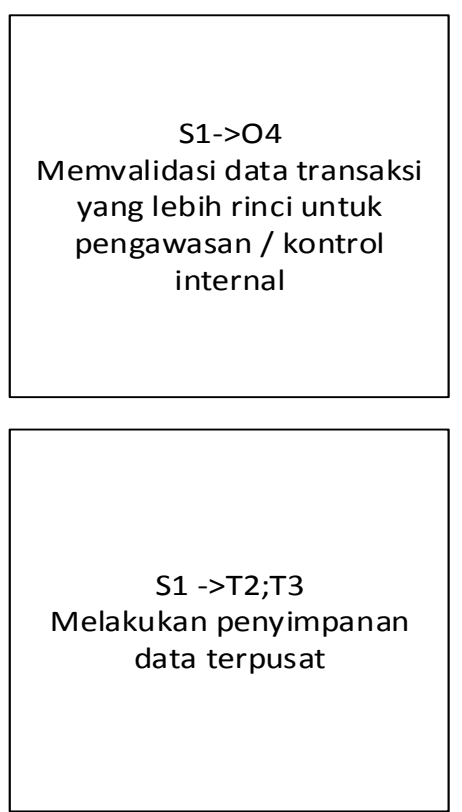

Gambar 5. Analisis SWOT
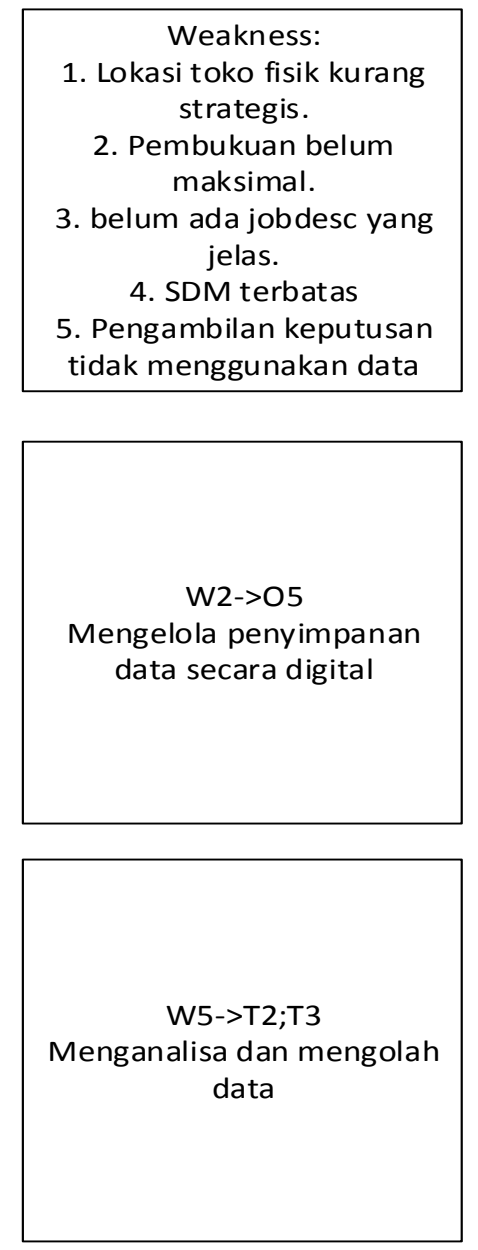

3. S -> T: Melakukan penyimpanan data terpusat. Dengan melihat kekuatan perusahaan yang memiliki modal cukup besar, Pemilik harus berhati-hati terhadap ancaman trend produk yang cepat berganti dan cost yang tinggi untuk setiap produknya. Tidak sembarangan membeli dengan modal yang tinggi namun harus sesuai perhitungan. Perhitungan yang baik berasal dari data yang valid, salah satu aspek yang membuat data-data perusahaan valid perusahaan harus melakukan pengumpulan data terpusat. Seperti strategi sebelumnya yaitu mendigitalisasi pemasukan data, data-data tersebut harus di simpan secara terpusat agar celah terjadinya kesalahan dapat di minimalisasi dan data dapat dipertanggungjawabkan secara penuh oleh divisi tertentu.

4. W $\rightarrow \mathrm{T}$ : Menganalisis dan mengolah data. Setelah semua data tervalidasi dan terkumpul secara digital dan terpusat data dapat diolah dan dianalisis. Hasil dari olahan data tersebut akan menunjuang untuk peningkatan pembuatan keputusan yang dilakukan oleh pemilik dan atau eksekutif perusahaan, melihat adanya ancaman dari produk yang trendnya cepat berganti dan cost tinggi.

\section{Menentukan Solusi}

Mengambil dari strategi bisnis objektif penelitian ini memerlukan solusi dalam peningkatan visibitas pengambilan keputusan. Peningkatan visibilitas pengambilan keputusan dapat dilakukan dengan membantu pemilik atau eksekutif memperoleh data yang akurat dan dalam waktu yang tepat, dengan bantuan sistem informasi. Hal ini salah satunya dapat dilakukan dengan mengumpulkan data secara efektif dan efisien pada setiap proses bisnis. Berdasarkan penjelasan tersebut strategi bisnis objektif (strategic business objective) yang tepat bagi PT Sentra Wira Taktikal adalah Operational Excellence (Laudon \& Laudon, 2016). Operational Excellence adalah strategi perusahaan untuk selalu meningkatkan efisiensi operasionalnya dalam rangka meningkatkan profit (Laudon \& Laudon, 2016). Peningkatan efisiensi 
dan efektivitas operasional perusahaan salah satunya dengan memanfaatkan sistem informasi dan teknologi sehingga memudahkan perusahaan dalam mengumpulkan dan mengolah data.

\section{Identifikasi Kebutuhan}

Dalam diagram Business Challenge

Bundle (BCB) pada gambar 5 menjelaskan bahwa tujuan dari strategi - strategi SWOT yang dibuat bertujuan agar perusahaan dapat bertahan dalam melakukan bisnisnya. Bisnis bertahan dapat ditunjang dengan mengaplikasikan strategi bisnis objektif yaitu peningkatan pengambilan keputusan yang dapat berjalan ketika strategi-strategi dari analisis SWOT dijalankan dengan bantuan sistem informasi.

Terdapat 3 cara untuk meningkatkan pengambilan keputusan yaitu :

1. Dokumen harus tervalidasi

2. Penyimpanan data secara digital dan terpusat

\section{Analisis Data.}

Untuk melakukan validasi dokumen (1) dan penyimpanan data (2) secara digital PT Sentra Wira Taktikal memerlukan data antara lain : purchase order, bukti bayar, sales order, delivery order, kwitansi, invoice, dan packing list. Sedangkan untuk melakukan analisis data (3) perusahaan memerlukan dashboard (yang merupakan laporan dari data yang telah diperoleh sebelumnya).

Validasi data yang perlu dilakukan oleh PT Sentra Wira Taktikal adalah dengan cara memeriksa data sales order dan packing list agar tidak ada kesalahan dalam penagihan ke konsumen, maka dari itu perlu adanya data sales order dari divisi penjualan dan packing list dari Gudang. Begitu pula dengan transaksi lainnya yang akan menggambarkan mengapa data-data tersebut diperlukan untuk strategi tertentu.

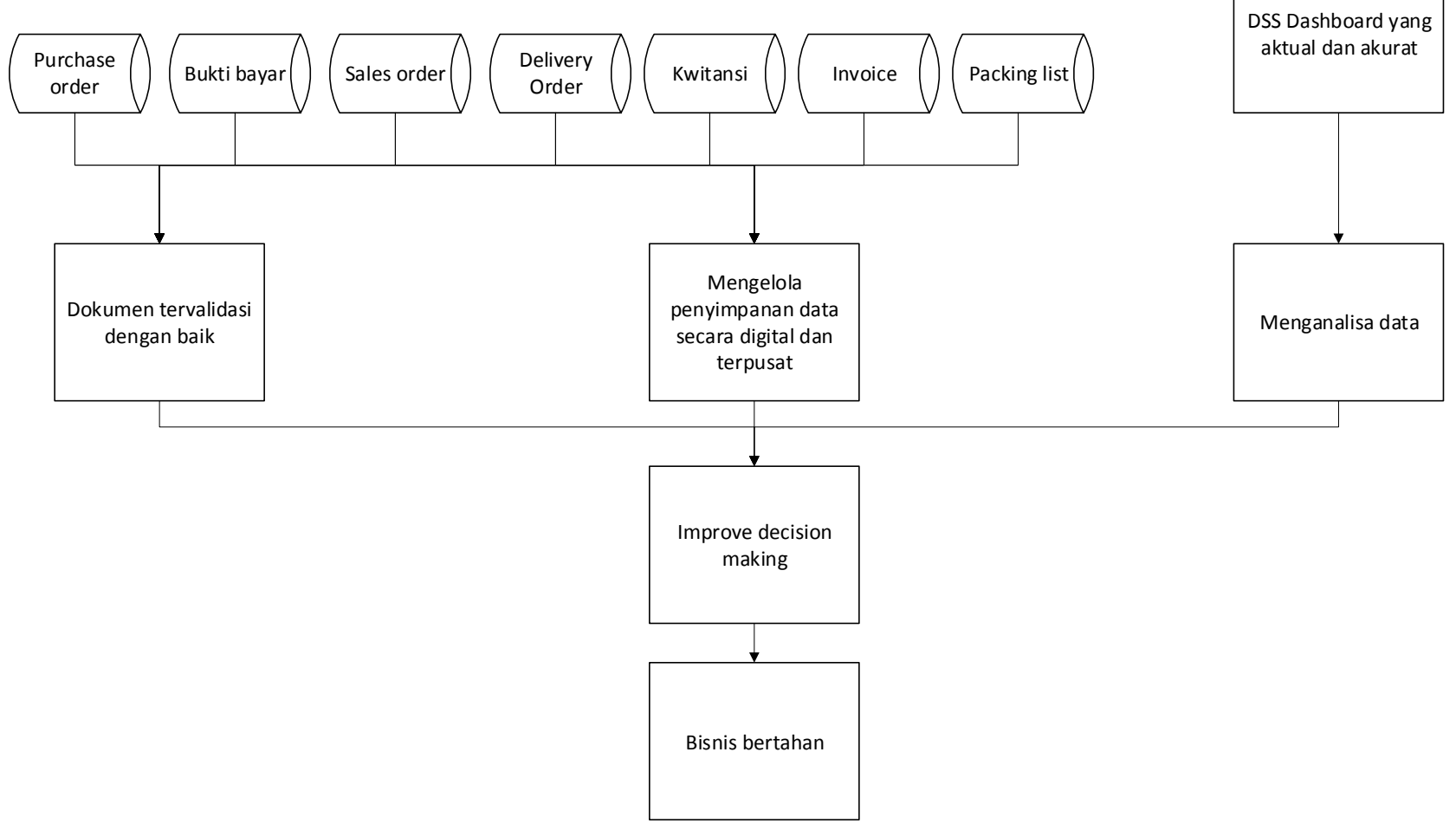

Gambar 6. Business Challenge Bundle (BCB) 


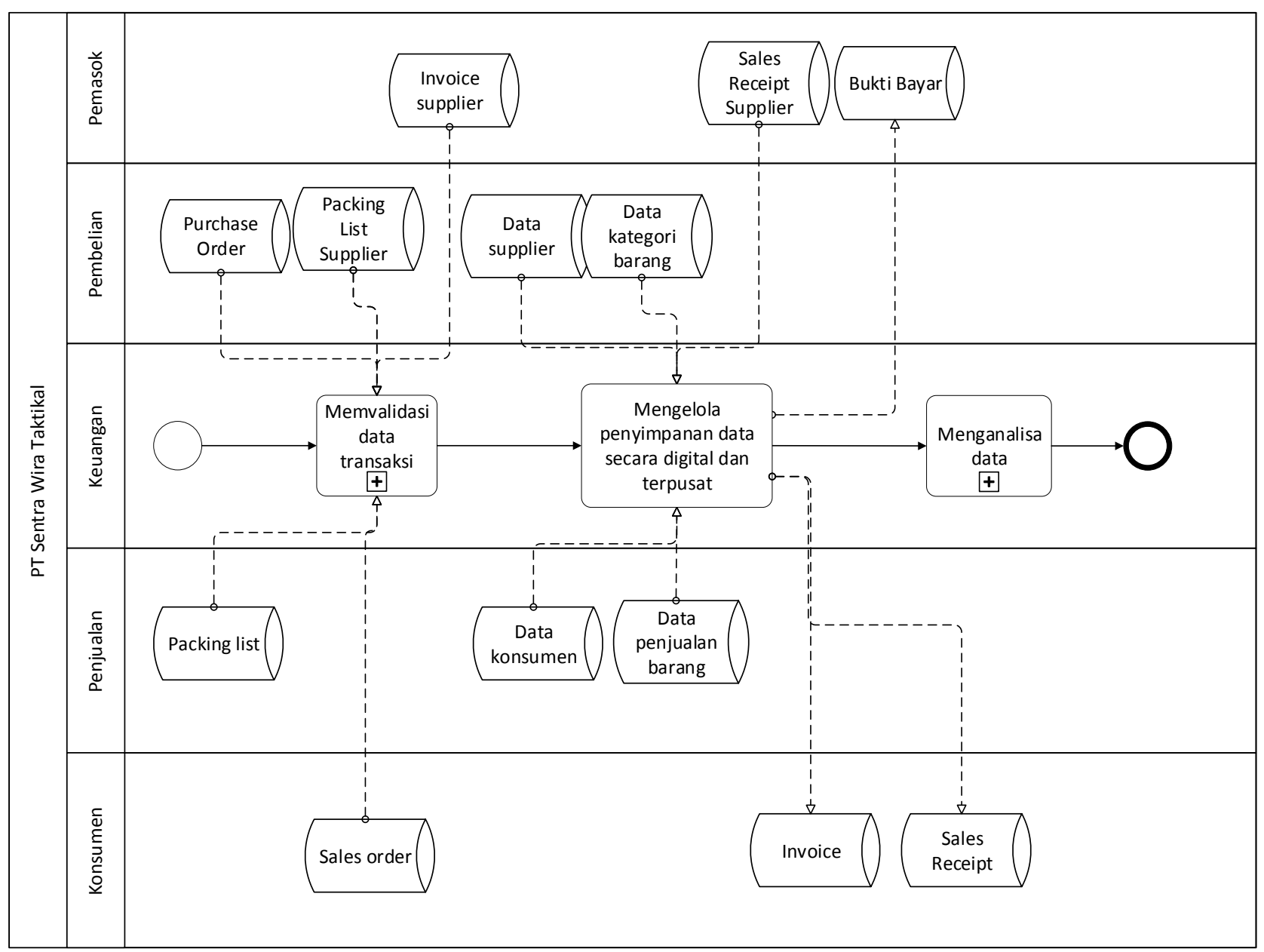

Gambar 7. BPMN level 0 Prosedur Kegiatan Keuangan

\section{Usulan Prosedur}

Gambar 6 menjelaskan proses bisnis untuk mencapai strategi-strategi yang sudah direncanakan di BCB. Diawali dengan memvalidasi data transaksi pembelian dan penjualan. Proses validasi data transaksi pembelian membutuhkan interaksi antara divisi keuangan dengan divisi pembelian sedangkan proses validasi data transaksi penjualan melibatkan divisi keuangan dengan divisi penjualan. Proses validasi data bertujuan untuk memastikan bahwa data yang diinput ke dalam sistem merupakan data yang benar berdasarkan hasil sinkronisasi data antar divisi yang berbeda. Proses validasi data dalam penelitian ini masuk ke dalam jenis sistem informasi TPS di mana proses ini membantu perusahaan mencatat dan menyimpan data yang valid.

Di samping itu, proses kedua yaitu mengelola penyimpan data secara digital dan terpusat juga merupakan bagian dari TPS. Di mana data yang telah tercatat pada proses pertama disimpan di dalam sistem. Jika melihat pada gambar 6 dan 7, penyimpanan data ini ditunjukkan dalam simbol tabung dan biasanya disebut sebagai database.

Setelah semua data terkumpul dan tervalidasi dengan baik, selanjutnya data akan masuk ke proses ketiga yaitu analisis data. Proses analisis data merupakan bagian dari manajemen information systems (MIS). Pada bagian ini, secara otomatis sistem akan menganalisis data yang terkumpul menjadi laporan-laporan rutin perusahaan seperti : laporan penjualan per bulan per produk, laporan laba perusahaan per bulan, dan lain sebagainya.

\section{Prosedur Validasi Data}

Gambar 7 merupakan proses memvalidasi data antara pembelian dan akutansi. Data yang digunakan adalah purchase order yang dibuat oleh divisi pembelian, lalu invoice dan packing list yang berasal dari pemasok. Jika terjadi ketidaksesuaian data antara ketiga dokumen tersebut, divisi akutansi perlu menolak ketiga dokumen tersebut serta menghubungi divisi pembelian sebagai penanggung jawab proses beli barang PT Sentra Wira Taktikal. Jika ketiga dokumen sesuai, divisi akutansi lanjut ke proses 
selanjutnya yaitu mengecek kesediaan saldo perusahaan.

Jika saldo perusahaan kurang, maka divisi akuntansi perlu menghubungi pihak pemasok untuk mengajukan kredit atau meminta tenggat waktu tertentu. Jika saldo perusahaan cukup, perusahaan akan membayar secara tunai. Hasil pembayaran perusahaan perlu dengan menyertakan bukti bayar sebagai arsip perusahaan serta bukti ke pemasok.
Setelah proses bayar selesai, divisi akutansi perlu menghubungi pemasok untuk meminta kwitansi dari pemasok.

Proses ini berguna untuk mendeteksi tidak ada kelebihan membayar, kekurangan barang diterima, dan perusahaan dapat melakukan komplain jika data tersebut tidak sesuai. Setelah semua tervalidasi maka kegiatan transaksi akan aman untuk dilakukan. Semua data yang dihasilkan dari kegiatan tersebut harus di simpan untuk kegiatan selanjutnya yaitu mengolah datadata untuk dianalisis.

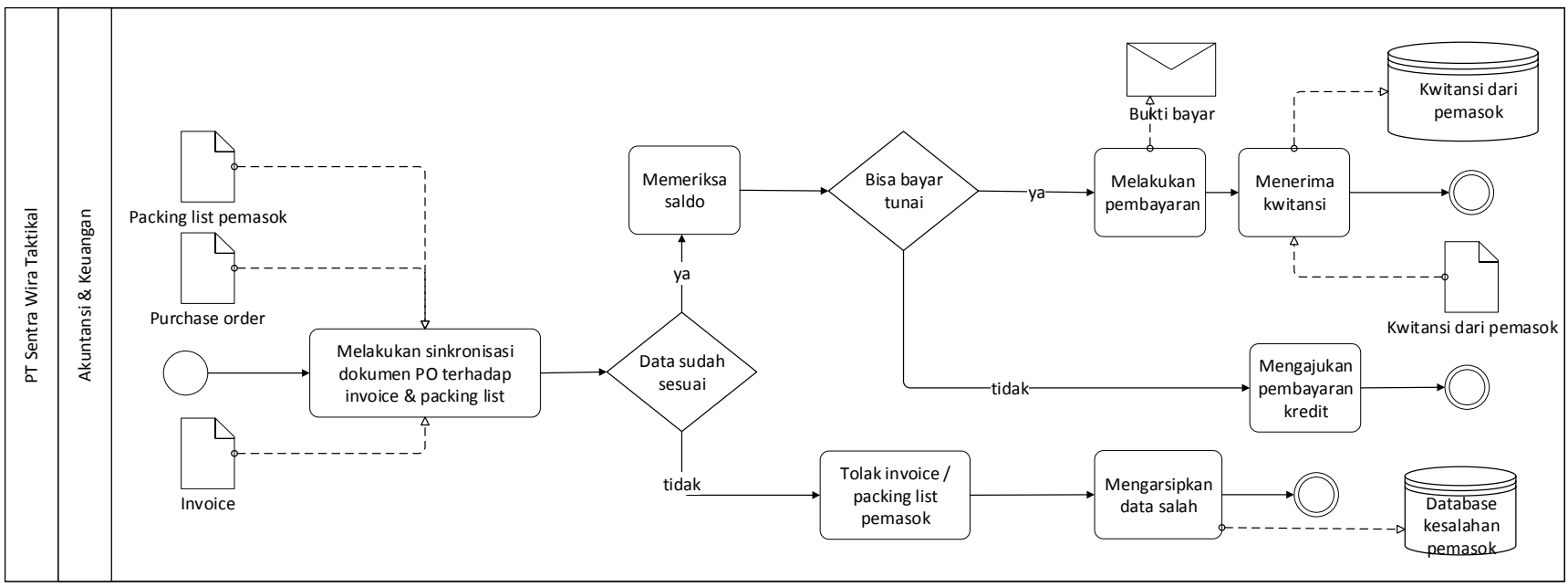

Gambar 8. BPMN collapsed validasi data untuk pemasok

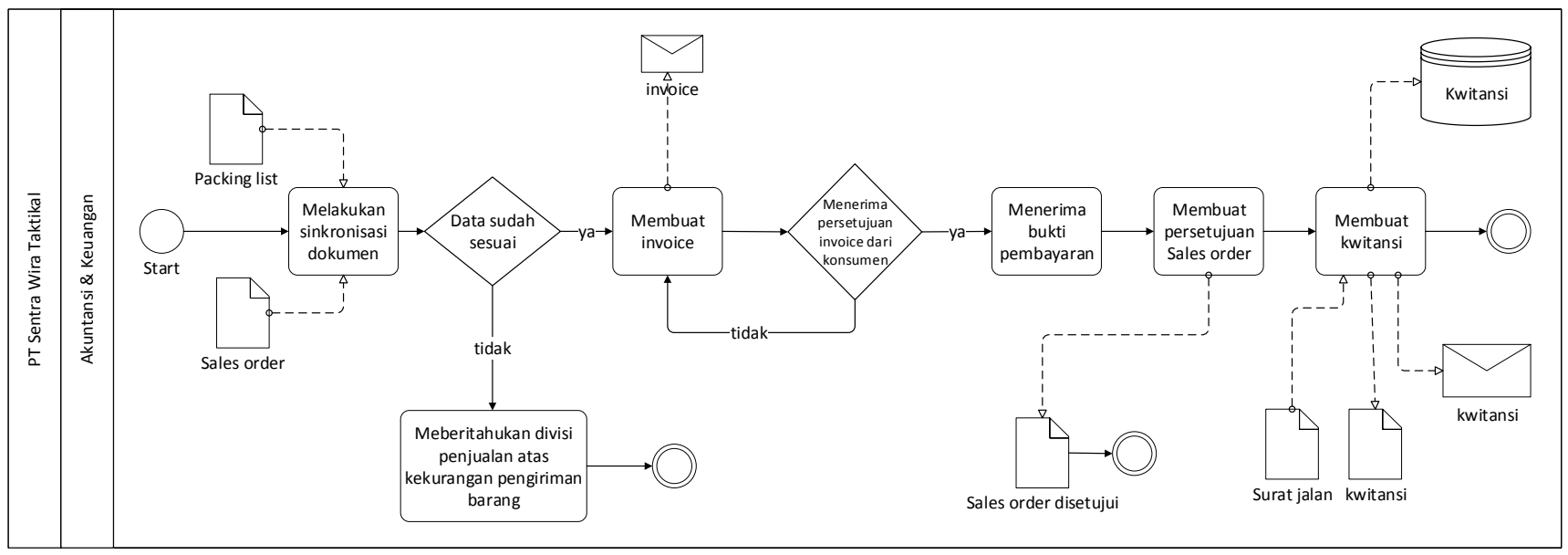

Gambar 9. BPMN collapsed validasi data untuk konsumen

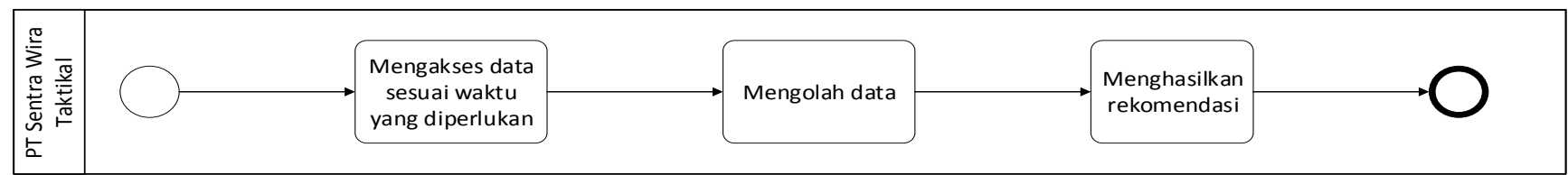

Gambar 10. BPMN Collapse 2

Sama seperti gambar 7, gambar 8 merupakan kegiatan memvalidasi data transaksi. Namun gambar 8 merupakan proses yang dilakukan antara divisi akuntansi dan divisi penjualan. Data yang dipakai untuk memvalidasi proses adalah sales order yang dibuat oleh 
konsumen dan packing list dari penjualan. Jika tidak sesuai, divisi akuntansi perlu meninjau ulang dengan menghubungi divisi penjualan. Jika kedua dokumen tersebut sesuai maka divisi akutansi dapat langsung membuat invoice untuk melakukan penagihan ke konsumen.

Setelah invoice terkirim ke konsumen, divisi akuntansi akan menunggu pembayaran. Jika konsumen sudah membayar, divisi akuntansi akan menerima bukti bayar, lalu divisi akuntansi akan menyetujui sales order yang dibuat oleh divisi penjualan.

Setelah itu divisi akutansi akan membuat kwitansi bila barang telah dikirim ke konsumen dengan menerima bukti surat jalan.

Adapun proses ini bermanfaat untuk mendeteksi tidak adanya kesalahan dalam pengiriman, penagihan ke konsumen secara tepat, dan dapat memonitor keluarnya barang. Setelah semua tervalidasi maka kegiatan transaksi akan aman untuk dilakukan. Semua data yang dihasilkan dari kegiatan tersebut harus disimpan untuk kegiatan selanjutnya yaitu mengolah data untuk dianalisa.

\section{Prosedur Pengelolaan Penyimpanan Data secara Digital dan Terpusat}

Proses ini dapat dilakukan bila perusahaan memiliki teknologi yang memadai seperti hardware, software, networking, database. Hardware seperti kelengkapan komputer pada umumnya, adapun hardware yang mendukung adalah yang dapat menjalankan software perusahaan (seperti hasil rancangan) dimana diperlukannya integrasi data dari masing-masing divisi yang mana diperlukan komputer yang berbeda-beda untuk masing-masing divisi.

Dengan adanya software, perusahaan dapat menjalankan proses bisnis yang terintegrasi antara divisi yang satu dengan yang lainnya. Hal ini dapat terlihat jika divisi penjulan telah membuat sales order, bagian akutansi dan keuangan dapat melihat hasil tampilan sales order di layar destop mereka tanpa memiliki kewenangan untuk mengganti data tersebut. Di sisi lain, bentuk formulir (tampilan) untuk dokumen formal perusahaan perlu distandarisasi, sehingga bentuk dan komponennya selalu sama dari waktu ke waktu.
Di samping itu, untuk beberapa dokumen dari eksternal perusahaan dapat menungaskan pegawainya untuk melakukan scan dokumen sehingga penyimpanan datanya secara digital. Adapun proses penyimpanan data dari fisik ke formal ini perlu dimasukkan ke dalam software yang ada, di mana pegawai perlu mengunggah bukti pendukung. Contohnya, ketika bagian akutansi dan keuangan akan membuat kwitansi, sebelum dapat membuat kwitansi tersebut, staf bagian akutansi dan keuangan perlu mengunggah scan bukti bayar dari pembeli untuk diupload ke dalam software tersebut.

Dengan adanya software terintegrasi ini penyimpanan data menjadi digital dan terpusat. Untuk mendukung hal ini diperlukan database (storage) yang memadai untuk menyimpan data dan informasi perusahaan. Bila melihat pada gambar 7 dan 8 , penyimpanan data secara digital dan terpusat ditunjukkan pada simbol berbentuk tabung seperti kwitansi dari pemasok pada gambar 7 dan kwitansi pada gambar 8. Hasil penyimpanan data yang biasanya disebut database, akan diolah secara otomatis oleh sistem menjadi informasi rutin yang dapat diperoleh perusahaan. Informasi rutin yang dimaksud antara lain : jumlah pendapatan per hari, jumlah pengeluaran per hari, jumlah kwitansi yang diterima perusahaan per hari, dan lain sebagainya. Oleh sebab itu, proses pengelolaan penyimpanan data secara digital dan terpusat merupakan sistem informasi manajemen.

\section{Prosedur Pengolahan Data}

Hasil penyimpanan data di dalam database yang dilakukan pada tahap sebelumnya, akan diolah lebih lanjut pada tahap ini. Prosedur pengolahan data pada tahap ini merupakan prosedur pengolahan data rutin seperti transaksi penjualan per hari, proses pembelian per hari, persedian per hari dan lain sebagainya yang merupakan aktivitas rutin.

Gambar 9 menjelaskan proses perusahaan dalam menganalisis data. Diawali dengan mengakses data sesuai waktu yang diperlukan bermaksud bahwa pemilik dan atau eksekutif dapat mengakses data terdahulu dan sekarang untuk berbagai macam keperluan. Data-data yang diakses merupakan hasil dari kegiatan sebelumsebelumnya. Jadi data tersebut sudah dipastikan 
valid dan tidak ada oknum yang dapat mengubahubah karena telah diinput secara terpusat, Selain itu data akan dengan cepat didapat karena sudah ada secara digital. Setelah itu data yang diakses akan diolah dengan bantuan sistem informasi yang akan menghasilkan laporan yang dapat digunakan oleh pemilik dan atau untuk pengambilan keputusan dan melakukan kegiatan berbisnis.

\section{Tampilan Pengguna}

\section{Tampilan Invoice}

Invoice yang dibuat merupakan perbaikan dari invoice yang telah dimiliki perusahaan saat ini. Di samping itu, invoice ini dibuat secara digital yang terhubung dengan sistem informasi terpusat sehingga terjadi sinkronisasi data antara nomor invoice dengan nomor sales invoice serta nomor kwitansi.

Tampilan invoice seperti yang ditunjukkan pada gambar 10 berguna untuk memudahkan pengguna, dan meminimalkan kesalahan input, karena adanya otomatisasi dalam penginputan data pada tampilan ini, Dengan mengisi no PO, kolom lain seperti nomor invoice, nomor order, tanggal, kuantitas, jumlah harga dan tujuan akan terisi otomatis berdasarkan database dari divisi penjualan. Pengguna hanya perlu menekan satu tombol untuk mencetak fisik invoice, dan menekan satu tombol untuk menyimpan data tersebut masuk menjadi database untuk diolah.

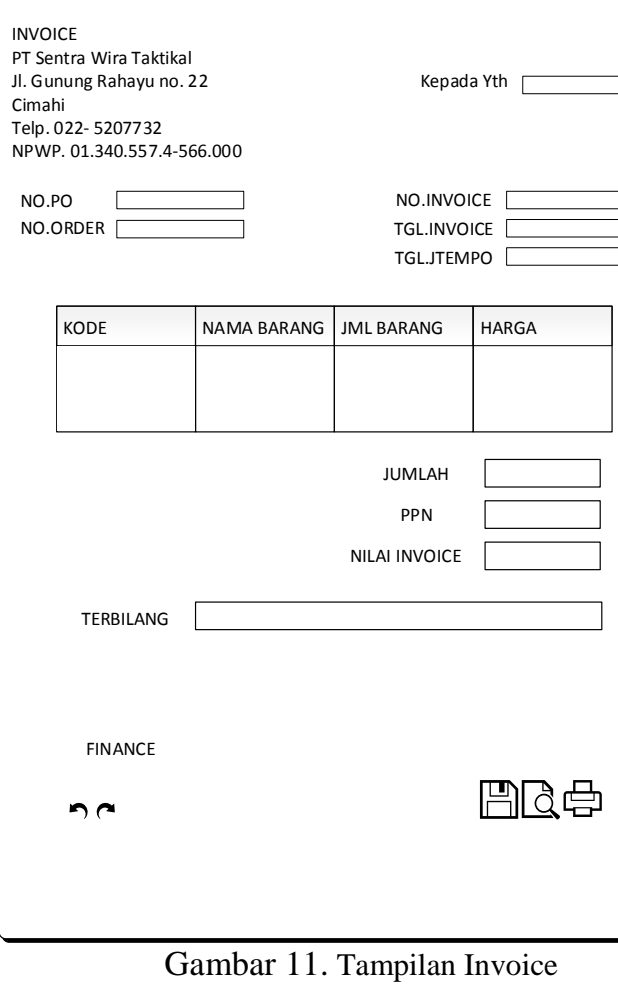

Gambar 11. Tampilan Invoice

\section{Tampilan Kwitansi}

Tampilan kwitansi perlu dipilih jika divisi akutansi sudah menerima bukti bayar dari konsumen. Tampilan ini berguna untuk memudahkan pengguna dan meminimalkan kesalahan input, karena adanya otomatisasi dalam penginputan data pada tampilan ini. Dengan mengisi no invoice, kolom lain seperti asal pembayar, jumlah uang, dan tujuan pembayaran akan terisi otomatis berdasarkan database invoice. Pengguna hanya perlu menekan satu tombol untuk mencetak fisik kwitansi, dan menekan satu tombol untuk menyimpan data tersebut masuk menjadi database untuk diolah. 


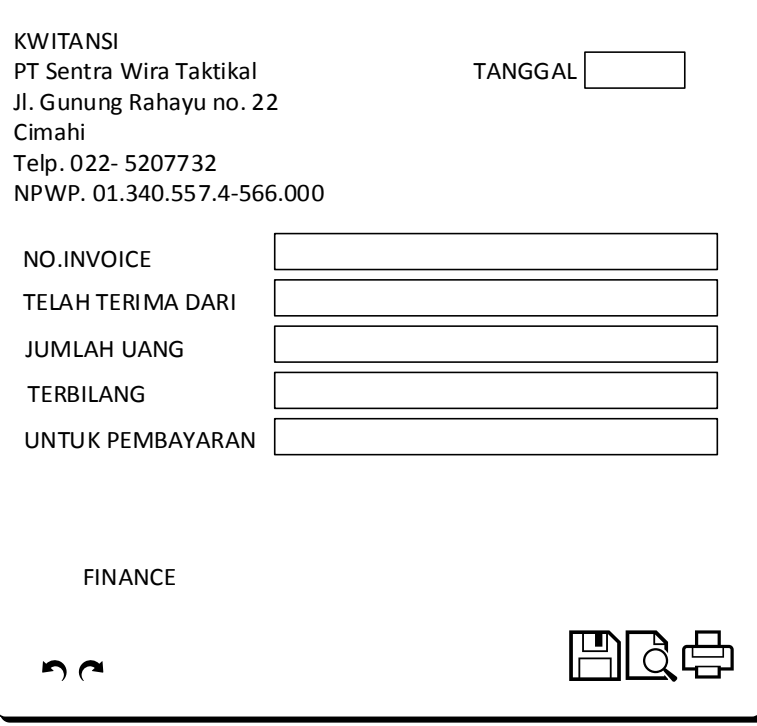

Gambar 12. Tampilan Kwitansi

\section{Tampilan Dashboard}

Tampilan Dashboard diperuntukan kepada pemilik atau eksekutif agar lebih mudah dalam mebaca laporan-laporan yang sudah diolah oleh sistem. Pada penelitian ini dibuat 3 tampilan dengan 3 indikator, yaitu: tampilan penjualan, pembelian, dan beban terhadap keuangan perusahaan. Tampilan ini diharapkan dapat membantu meningkatkan pengambilan keputusan oleh pemilik dam atau eksekutif perusahaan karena dengan tampilan ini pemilik dan atau eksekutif dapat mengetahui laku atau tidaknya suatu produk, trend produk, dan biaya yang harus dikeluarkan dari pembelian dan beban perusahaan.

Pada gambar 12 ditunjukkan informasi pembelian antara lain, total pembelian perbulan yang dapat dibaca dengan mudah karena menggunakan grafik sehingga pemilik dapat dengan mudah mengetahui pengeluarannya per bulan. Pemilik dan pihak eksekutif perlu melakukan analisis lebih lanjut untuk melihat apakah frekuensi pembelian yang dilakukannya selama ini sudah efektif atau belum. Di samping itu, bila mengacu pada pernyataan pemilik di Porter 5 's Force dimana pemasok PT Sentra Wira Taktikal umumnya berasal dari luar negeri, maka perusahaan sebaiknya menerapkan Economic Order Quantity untuk mengurangi biaya pemesanan barang termasuk di dalamnya biaya pengiriman (karena bea import cukup besar dan memakan waktu).
Bila melihat pada diagram pie, perusahaan dapat mengetahui produk yang paling sering dibeli untuk memenuhi kebutuhannya. Hasil pada diagram pie pembelian sebaiknya ditinjau ulang (disesuaikan) dengan diagram pie penjualan untuk melihat apakah produk yang selama ini dibeli sesuai dengan selera pasar, dan memastikan tidak ada produk yang tertimbun terlalu lama di gudang.

Pada gambar 13 ditunjukkan informasi penjualan antara lain, total penjualan perbulan yang dapat dibaca dengan mudah karena menggunakan grafik sehingga pemilik dapat dengan mudah mengetahui pada bulan mana penjualan memuncak dan menurun (high season dan low season). Hal ini berguna agar pemilik atau pihak eksekutif dapat memprediksi trend pada tahun berikutnya sehingga jumlah inventori yang disediakan sesuai dengan permintaan pasar. Di samping itu, pihak eksekutif perlu melakukan analisis lebih lanjut untuk mengetahui alasan mengapa pada bulan tertentu permintaan terhadap produk memuncak. Contohnya : apakah pada highseason tersebut terdapat banyak tanggal merah? apakah ada libur panjang?

Di samping itu, mengacu pada diagram pie di bawahnya, PT Setra Wira Taktikal dapat mengetahui produk apa yang paling diminati oleh konsumennya. Hal ini berguna baik untuk mengatur persediaan produk tersebut, atau meningkatkan promosi pada produk-produk yang kurang diminati seperti menyediakan promosi bundling dan sebagainya.

Pada sebelah kiri gambar 12 dan 13 ditunjukkan : transaksi, laba kotor dan saldo akhir tabungan perusahaan. Transaksi menunjukkan jumlah transaksi yang terjadi selama 1 tahun, laba kotor menunjukkan keuntungan perusahaan (belum dikurangi biaya operasional \& lain-lain), sedangkan tabungan perusahaan menunjukkan dana yang dapat digunakan perusahaan untuk menjalankan bisnisnya di periode selanjutnya.

Hal ini berguna untuk melihat gambaran besar perusahaan selama periode tertentu (kurun waktu 1 tahun). 


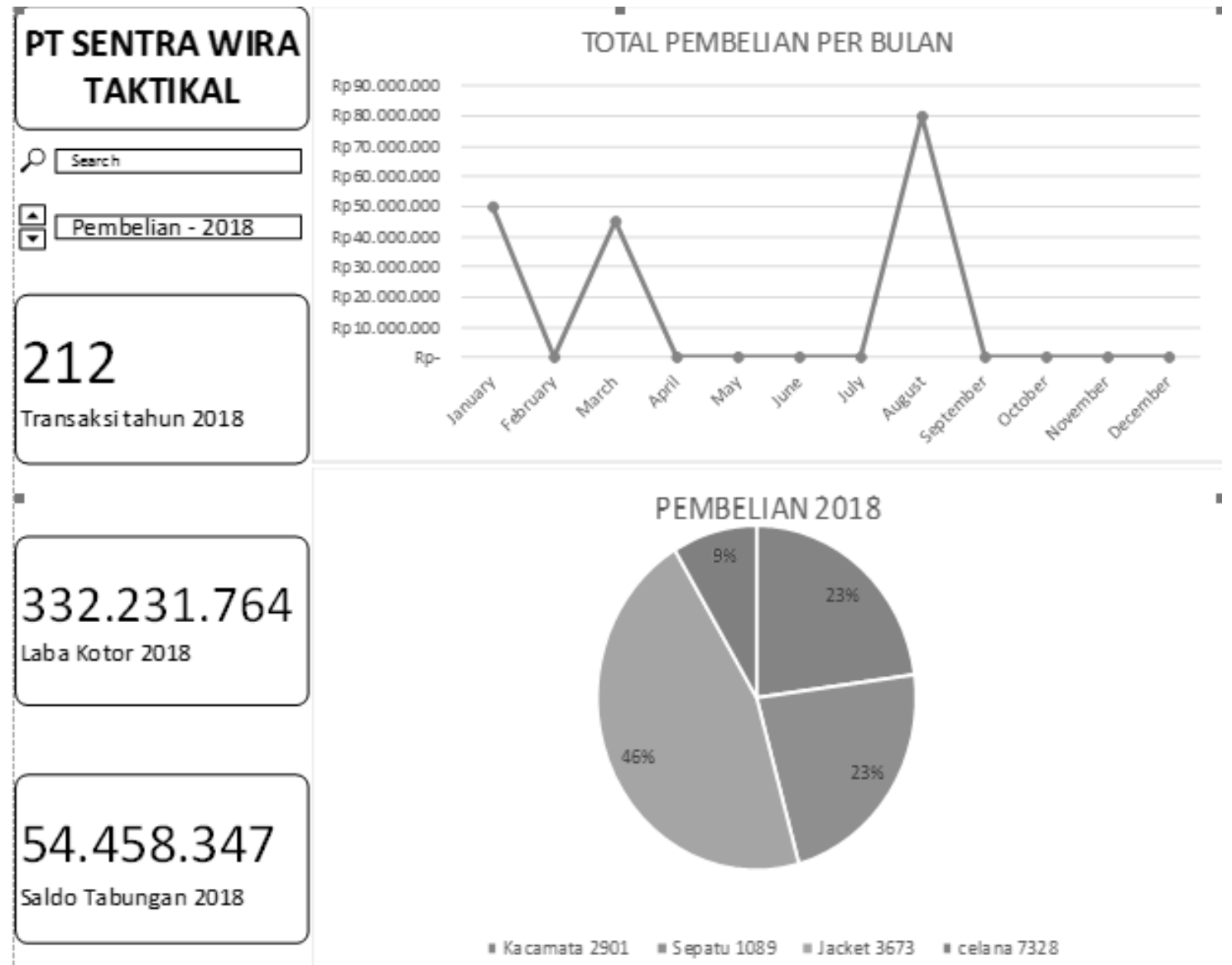

Gambar 13. Tampilan Dashboard (pembelian)

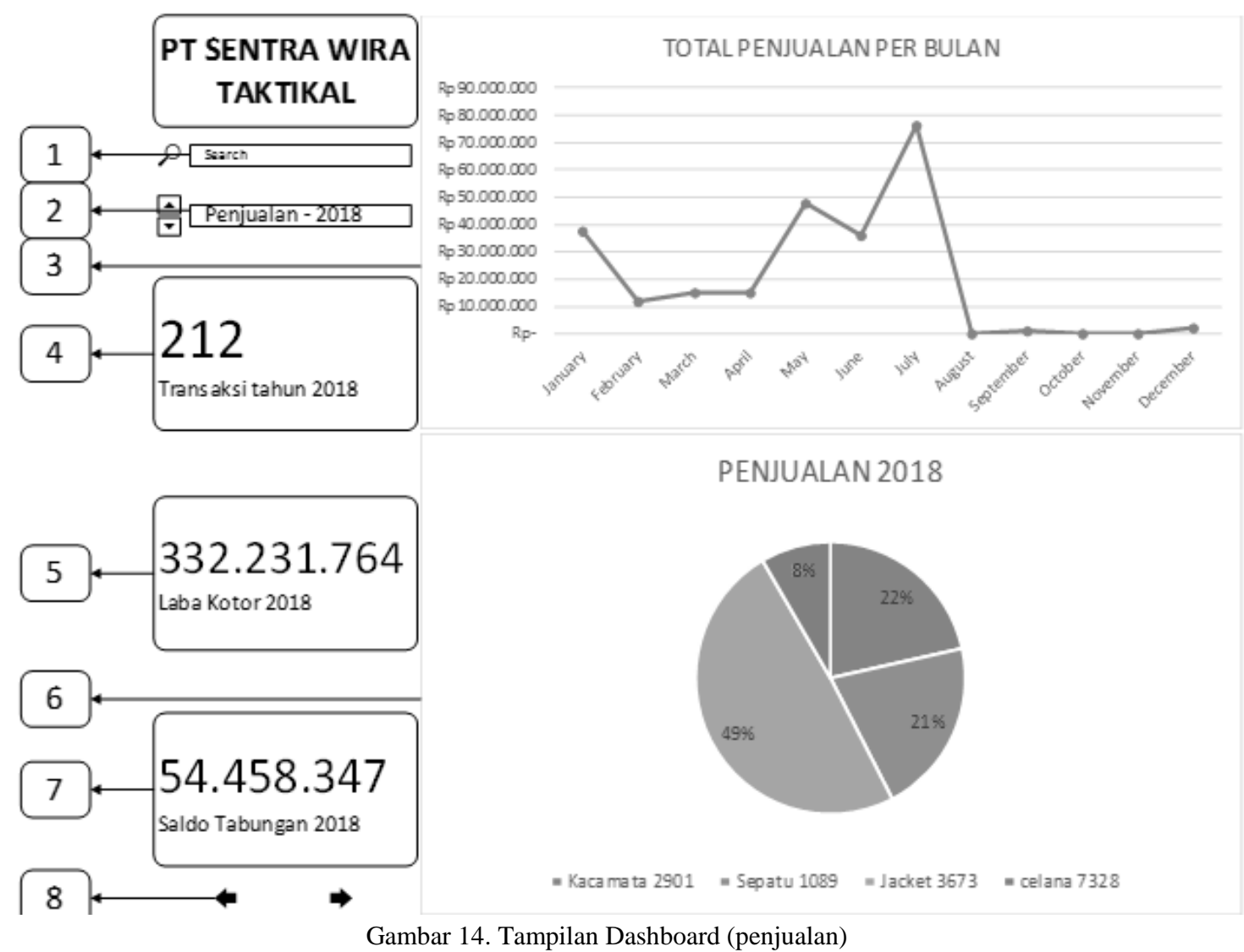


Adapun penjelasan atas tampilan dashboard pembelian (gambar 12) dan penjualan (gambar 12), yaitu:

1. Kolom 1 dipakai untuk membantu pengguna mencari suatu kata (nama barang, tanggal, dll).

2. Kolom 2 dipakai pengguna untuk memilih varibel yang ditampilkan beserta tahunnya (pembelian, penjualan, dan beban).

3. Tabel grafik bertujuan untuk menggambarkan naik turunnya suatu variable yang di analisis per bulannya. Tabel tersebut dapat di klik untuk mendapatkan rinciannya (dapat dilihat pada gambar 14). Perincian perhitungan seperti yang ditunjukkan pada gambar 14 dimaksudkan membantu perusahaan mengakumulasikan total penjualan atau pembelian (dalam rupiah) untuk masingmasing barang ataupun secara keseluruhan. Dengan adanya perincian perhitungan ini diharapkan dapat membantu perusahaan melihat dan memprediksikan aliran dana perusahaan sehingga ke depannya PT Sentra
Wira Taktikal dapat mengelola keuangannya dengan lebih baik berdasarkan data historis yang dimiliki oleh perusahaan.

4. Kolom 4 berisikan informasi dari hasil penghitungan seluruh transaksi selama satu tahun.

5. Kolom 5 berisikan informasi laba kotor yang diperoleh oleh perusahaan.

6. Tabel pie-chart bertujuan untuk menggambarkan porsi setiap produk terhadap varibel yang dianalisis. Tabel tersebut dapat di klik untuk mendapatkan rinciannya.

7. Kolom 7 berisikan informasi saldo bank terakhir kali sesuai pencatatan terakhir dari variabel - variabel yang diuji. Kolom ini dapat di klik untuk di tujukun kepada aplikasi bank terkait bagian mutase.

8. Tombol kembali dan selanjutnya bertujuan untuk memudahkan pengguna saat menginginkan tampilan terdahulu atau tampilan tahun berikutnya.

\begin{tabular}{|c|c|c|c|c|}
\hline Tanggal & January & February & March & April \\
\hline Kacamata 2901 & Rp 30.000 .000 & Rp 7.500 .000 & Rp 7.500 .000 & Rp 3.000 .000 \\
\hline Sepatu 1089 & & & Rp $\quad 6.000 .000$ & Rp 9.000 .000 \\
\hline \multicolumn{5}{|l|}{ Jacket 3673} \\
\hline celana 7328 & Rp 7.500 .000 & Rp 4.500 .000 & Rp 1.500 .000 & Rp 3.000 .000 \\
\hline TOTAL & Rp 37.500 .000 & Rp 12.000 .000 & Rp 15.000.000 & Rp 15.000.000 \\
\hline
\end{tabular}
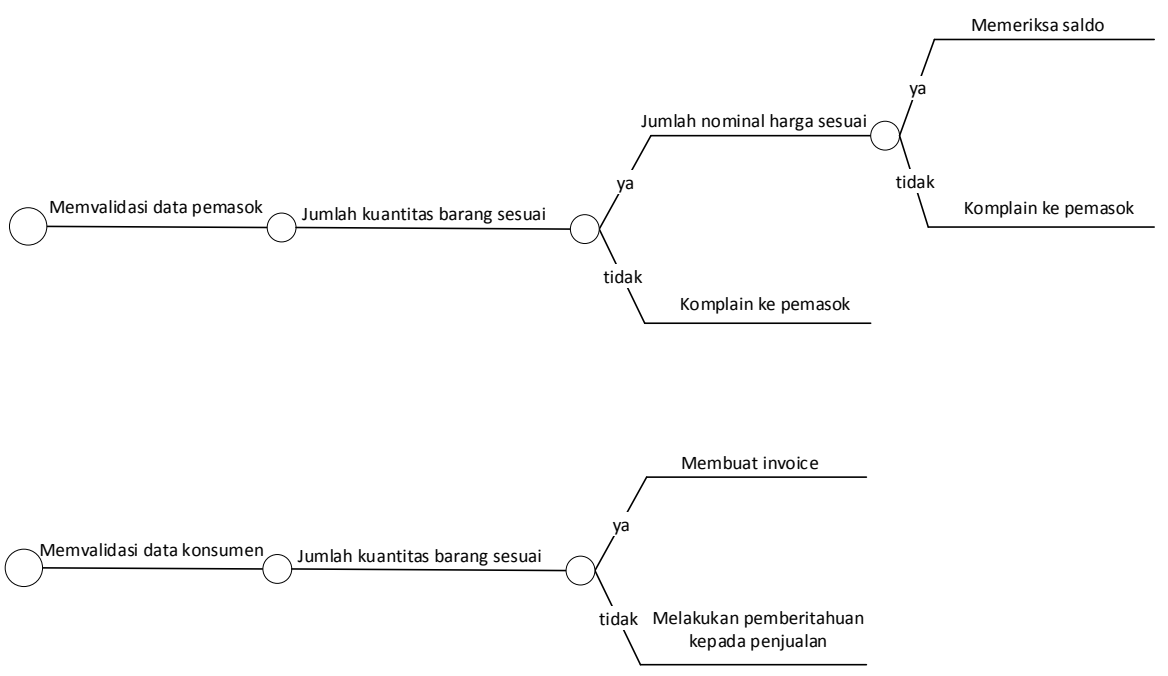

Gambar 16. Decision Tree 


\section{Logika Berpikir}

Logika berpikir yang diusulkan dibantu dengan diagram pohon keputusan, agar terlihat ada beberapa kemungkinan yang dapat dilakukan. Pohon keputusan yang penulis buat merupakan pohon keputusan untuk gateway memvalidasi data pada BPMN diatas. Komponen untuk pohon keputusan kegiatan memvalidasi data pemasok adalah jumlah kuantitas barang dan jumlah nominal harga yang ditagih oleh pemasok. Jika terjadi suatu kesalahan dari pemasok, PT Sentra Wira Taktikal memiliki hak untuk melakukan komplain hingga transaksi berjalan sesuai kesepakatan ataupun membatalkan transaksi tersebut. Jika komponen-komponen tersebut terpenuhi menjadi suatu kewajiban untuk PT Sentra Wira Taktikal untuk membayar tagihan. Komponen yang dipakai pada pohon keputusan kegiatan memvalidasi data konsumen adalah hanya perihal kuantitas barang. Barang yang dikeluarkan harus sesuai dengan sales order yang diterima oleh PT Sentra Wira Taktikal. Dan jika komponen tersebut terpenuhi, PT Sentra Wira Taktikal segera membuat invoice sesuai dari datadata tersebut.

\section{Tanggapan Pemimpin}

Pemilik setuju dengan konsep yang ditawarkan oleh penulis. Menurut pemilik, usulan sistem ini bisa membantu kegiatan akuntansi dan keuangan perusahaan. Dengan adanya grafik pada Dashboard yang dibuat, pemilik merasa terbantu karena tidak dipusingkan oleh angka-angka yang cukup banyak. Pemilik juga sadar bahwa aktivitas memvalidasi data, pencatatan data, dan mengolah data merupakan kegiatan dasar yang dangat mempengaruhi sistem informasi yang akan dipakai.

\section{KESIMPULAN}

Berdasarkan hasil penelitian, dapat disimpulkan bahwa PT Sentra Wira Taktikal memiliki kendala dalam mengambil keputusan karena tidak tersedianya informasi yang memadai dari transaksi terdahulu. PT Sentra Wira Taktikal perlu untuk memvalidasi data transaksi, mencatat data secara digital dan terpusat serta mengolah data menjadi informasi yang lengkap sehingga mampu meningkatkan visibilitas pengambilan keputusan dapat tercapai.

Dengan memenuhi kebutuhan tersebut, perusahaan mampu untuk menghadapi tantangan dan kondisi internal dan eksternal saat ini seperti yang diuraikan di dalam analisis SWOT. Dengan menyediakan data yang tervalidasi perusahaan mampu memaksimalkan aktivitas internalnya dan memenuhi secara rutin kebutuhan TNI/Polri. Data terpusat dan terdigitalisasi membantu perusahaan untuk memaksimalkan pembukuan divisi akutansi dan keuangan, menyesuaikan perusahaan dengan perkembangan teknologi dan tren yang cepat, dan menekan biaya antara lain biaya penyimpanan data fisik. Hasil olahan data membantu perusahaan dalam pengambilan keputusan, memenuhi tren pelanggan berdasarkan historis, dan membantu perusahaan dalam mengatur anggaran biaya.

Ketiga kebutuhan utama PT Sentra Wira Taktikal dapat dipenuhi dengan membangun sistem informasi yang baik antara lain melalui membangun prosedur bisnis yang baru dan tampilan pengguna dari hasil analisis data digital. Data yang diperlukan untuk memaksimalkan prosedur antara lain: data pemasok, purchase order, surat jalan dari pemasok, tagihan pemasok, data kategori barang, bukti bayar, sales order, surat jalan pelanggan, kwitansi, sales invoice, dan data pelanggan.

Tampilan pengguna terdiri dari (1) formulir digital yang dapat membantu divisi akutansi dan keuangan PT Sentra Wira Taktikal menginput data sales invoice dan kwitansi (bukti bayar) serta (2) tampilan dashboard yang dapat membantu pihak menejerial melihat aktivitas perusahaan yang menjadi dasar pengambilan keputusan. Penelitian ini tidak membahas pencatatan data awal (data yang digunakan untuk divalidasi) dikarenakan penelitian ini berfokus pada divisi akutansi dan keuangan yang umumnya hanya memproses informasi yang telah dihasilkan oleh divisi penjualan dan divisi pembelian (sales order, purchase order, surat jalan, dan lain sebagainya).

Di samping itu, penelitian ini terbatas pada pengolahan data sederhana yang dapat memberikan informasi bagi pengguna namun 
belum ditelusuri lebih lanjut seperti memberikan saran-saran keputusan dengan menggunakan decision support system. Oleh sebab itu, penelitian selanjutnya juga dapat meneliti mengenai decision support systems bagi PT Sentra Wira Taktikal.

\section{DAFTAR PUSTAKA}

Creswell, J. (2007). Qualitative Inquiry \& Research Design Choosing Among 5 Approaches 2nd. London: Sage Publication, Inc.

Dul, J., \& Hak, T. (2008). Case Study Methodology in Business Research. Elsevier.

Gunawan, A. (2012). Information access for SME's in Indonesia: A study on the business performance of garment manufacturers. Enschede: Ipskamp Drukkers.

Laudon, K. C., \& Laudon, J. P. (2016). Management Information System. London: Pearson.

O'Brien, J. (2010). Introduction to Information System 15th edition. New York: McGrawHill Irwin.

Shneiderman, B., \& Plasant, C. (2005). Designing User Interface. Maryland: Pearson Education Inc.

Stiehl, V. (2014). Process-Driven Applications with BPMN. Walldorf: Springer.

Sugiyono. (2014). Model Penelitian Bisnis. Bandung: Alfabeta.

Thompson, A., Peteraf, M., Gamble, J., \& Strickland III, A. (2016). Crafting and Executing Strategy: The Quest For Competitive Advantage, Concepts and Cases (20th ed.). New York: McGrawHill/Irwin.

Tsang, S., Kao, B., Yip, K., Wai, S., \& Dan Lee, S. (2009). Decision Trees for Uncertain Data. IEEE Transactions on Knowledge \& Data Engineering, 441 - 444.

United States Census Bureau. (2018, Juli 1). most populous countries. Retrieved from census.gov:

https://www.census.gov/popclock/world

Yin, R. (2011). Qualitative Research from Start to Finish. New York: The Guilford Press. 